\title{
La judería murciana en la época de los Reyes Católicos
}

\author{
JUAN TORRES FONTES
}

La historia de la judería murciana bajo soberanía de Castilla (12661492) ofrece en la totalidad de sus perspectivas una imagen precisa: seguridad y con ella la actitud del concejo de protección, comprensión y objetividad, que a su vez proporcionaron una convivencia compensada, efectiva y lúcida en su coexistencia. Este comportamiento del concejo murciano fue compartido en todo tiempo por obispos y cabildos, pues sus acuerdos estuvieron siempre encaminados a proteger y amparar a quienes como vecinos tenían el deber de defender. $Y$ lo hicieron con rectitud y arrostrando dificultades. Fue siempre norma concejil hacer públicas y recoger en sus actas y cartularios cuantas misivas reales de diverso contenido les llegaba, así como sus propias ordenaciones, e igualmente es perceptible cómo oficialmente se acataban disposiciones que afectaban desfavorablemente a los judíos y cómo pocas veces se cumplían. Y lo contrario, acuerdos en que se manifestaba su forma de pensar y hacer, sus propósitos de continuar cumpliendo su justo obrar como norma de gobierno, con profundo sentido humano y siempre con respeto a las diferencias religiosas, ya que, en ocasiones, improvisaron con criterio objetivo, conscientes de su responsabilidad, decisiones contrarias a cuanto pudiera significar o provocar alteraciones o presentar imagen distinta de la realidad que ellos conocían y querían mantener.

Desde este lado murciano no deja de causar cierto asombro la considerable distancia que apreciamos entre lo que se dice y escribe sobre los judíos castellanos y la imagen que obtenemos tras conocer y analizar documentalmente el desarrollo de la judería de Murcia y, ahora, en este caso, en la época de los Reyes Católicos. No creo que sea un caso insólito, aunque pudo serlo en determinadas circunstancias y tiempos, pero nunca con ese carácter general que se precisa en los siglos XIII-XV. Una judería importante, pues ocupa el cuarto puesto en el número de vecinos de las poblaciones castellanas en el reparto del servicio y medio 
servicio de 1474, que pasaría a ser el once en la asignación de castellanos en el año 1490.

En estos diecisiete años encontramos amplias muestras documentales de la actitud del concejo, que a su vez, en líneas generales, representaba a la totalidad de la población, pese a ese silencio de las clases más bajas, sin voz, pero que ocasionalmente en períodos de crisis se hacía oír. Política concejil que respondía a una tradición secular no trastocada o alterada por esporádicos apasionamientos de grupos o determinadas personas, más guiadas por apetencias o agravios ecorı́micos que religiosos. De aquí que ante supuestos intentos o corredurías de palabras de carácter antijudío, la reacción concejil fuera inmediata, rechazando rumores y afirmar que de producirse cualquier alteración sería en "grand disfamaçion desta çibdad». A su lado, antes y después, el adelantado con declaración pública que «los judíos le son encomendados por el rey» y en otra ocasión respecto a actitudes antijudías, que eran «en menospreçio de la justicía e deserviçio del rey».

Otro hecho, tan público como obligado y significativo, en que el concejo hubo de asumir su obligado protagonismo pero también su criterio político, fue cuando por orden del pesquisidor real Juan de la Hoz, en cumplimiento de los acuerdos de las Cortes de Madrigal de 1476 y las de Toledo de 1480, mandaba pregonar el 12 de diciembre de 1481 la obligación de los judíos de ir señalados fuera de la judería con «roldetes de paño colorado en los pechos en la parte izquierda». Pero, en el mismo día, otro pregón hacía saber que uninguna ni algunas personas de qualquier ley, estado o condiçion que sean, non sean osados de aqui adelante de dezir ni fazer a los dichos judios o moros cosa ninguna sobre la dichas señales que lieven ni por ellas, de que ynjurias e ofensas les pudiera venir ni causar, aperçibiendoles que sy lo contrario fizieren se estaran veynte dias en la cadena e pagaran la pena que por el señor corregidor les fuere impuesta».

En el transcurso de estos años, la tolerancia murciana con las minorias religiosas no se altera ni deteriora; la relación ciudadana se mantiene de forma semejante a todas las fases históricas que pudiéramos establecer en la historia de la judería murciana. Tanto porque profesión, diversidad de oficios y múltiples actividades - comercio, industria, artesanía y amplitud de servicios, algunos de ellos especializados - suponían una permanente relación humana, de trato y contacto amistoso, como de necesidad, ni las disposiciones legales ni la malquerencia que hubiera podido surgir al generalizar en la grey judía las extorsiones o demasías de los agentes fiscales, en su mayor parte judíos, no se frenó o detuvo esta armónica covecindad. No hubo hostilidad ni se fomentaron actitudes pa- 
sionales por razones religiosas y la realidad de todos los días presentaba la misma faz, armonía bastante más estrecha de cuanto se ha dicho entre sociedades diferenciadas por religión, poder, número de población, medios y modos de vida, y en su centro el concejo, regulador de las relaciones.

Hemos procurado que nuestra aportación, basada fundamentalmente en los acuerdos concejiles, se mantenga en la misma línea de la verdad oficial, toda vez que su objetividad es evidente, respuesta a la política que corregidores y regidores mantuvieron en todo tiempo, con decisiones que pudiéramos calificar de justas, y que documentos reales y particulares lo confirman. División en distintos apartados de desigual extensión por el contenido temático y por la documentación que ofrecen y, por evitar prolijidad, renunciamos a la inclusión de apéndice documental y reducimos las citas a la mención de aquellas fuentes impresas consultadas, remitiendo el resto a las actas concejiles, cartularios reales y Registro General del Sello.

\section{LA JUDERÍA}

Una referencia concejil de comienzos del siglo XV nos dice que estaba «çercada e situada desde que Murçia es de christianos». Referencia aplicable tanto al siglo XIII que a 1942, puesto que no hubo traslado ni cambio, aunque sí ampliación. Cumpliendo una norma eclesiástica, ya concretada en el Concilio Lateranense de 1215 y que, posteriormente, se ocuparía Alfonso $X$ en las Partidas, dispuso el rey Sabio cuando recupera la ciudad de Murcia en 1266 la separación de judíos y moros al ordenar "que ningund judio en la çibdad de Murçia non more entre christianos, mas que aya su juderia apartada en la puerta de Orihuela en aquel logar que los partidores les dieron por nuestro mandado» 1 .

Los partidores cumplieron la disposición real, aunque con cierto detenimiento a causa de haber concedido casas en aquella zona urbana a cristianos, por lo que les hubieron de compensar a sus propietarios con generosas donaciones en la huerta; fueron más de treinta y entre ellos el labrador Ramón Abellán, al cual por las casas «que avie en el barrio de los judios» se le entregaron cincuenta tahúllas, cantidad superior a las dotaciones concedidas a los caballeros mayores en el Repartimiento.

TORRES Fontes, «Los judíos murcianos en el siglo XII", Murgetana, n. ${ }^{16}$. Murcia 1962, págs. 5-20. 
La extensión superficial de la judería pudo alcanzar entonces unas tres hectáreas, que sería ampliada tiempo después hasta superar las cinco hectáreas en el transcurso del siglo xv. Los intentos de aumentar su espacio urbano se sucedieron entre protestas y recelos de los vecinos cristianos, no siempre fallidos $y$, en cambio, no parece que hubiera oposición a que mantuvieran sus talleres y tiendas en las zonas centrales de la ciudad. El concejo no fue riguroso en cumplir acuerdo prohibitivos, e incluso es conocido que en 1453 dio su conformidad a que los judíos pudieran incorporar lo que había sido casa de la moneda, con autorización para hacer portales a ambos lados de la calle y tener entrada por ella a la judería. Gente popular derribaron las puertas y, aunque los regidores adoptaron el acuerdo de castigar duramente a los causantes, el rabino y representantes de la judería acudieron al concejo y solicitaron que todo quedara sin efecto, pues el «desvarío» de algunos cristianos podría tener consecuencias graves para ellos, por lo que todo volvió a su estado anterior. Pero también conocemos que en 1479 el recaudador mayor de las rentas reales, a cuyo cargo había estado la casa de moneda y gozaba entonces de toda la confianza real, moraba «en la puerta de la juderia».

En 1475, el concejo ordenaba a los judíos que habían comprado casas fuera de la judería que las vendieran a cristianos por el mismo precio que habían abonado, avisando, al mismo tiempo, a Bartolomé Vidal que la casa que había adquirido cerca de la judería la tuviera para sí y no la alquilara o vendiera a judíos bajo pena de 10.000 maravedíes. Dos años más tarde continuaba la expansión urbana de los judíos pese a prohibiciones y recordatorios, hasta nueva disposición «por quanto los judios de la juderia de la dicha çibdad en perjuizio de las christianos e contra deffendimiento de las leyes e del dicho conçejo conpran casas fuera del çercuyto de su juderia que por el dicho conçejo le es asignado, en lo qual non le deve ser dado lugar por los daños que se esperan seguir». La decisión concejil fue que las perdieran quienes las tuvieran y con aviso que si algún «judio morava entre christianos fuera del dicho çercuyto» pagaría 600 maravedíes cada vez que así lo hiciera. Prohibición sólo parcialmente cumplida, pues en otras ocasiones les daban plazo de ocho días para reintegrarse a la judería o quedaran sin efecto los contratos de compraventa, como en 1477 cuando obligó a Ginés Manresa a devolver la señal de compra recibida por David Aventuriel por unas casas en la collación de San Lorenzo, cercanas a la judería, si bien con la nota singular del voto en contrario de dos regidores, que consideraban legal la compra, siempre que el judío «non more en ella». Una cosa era propiedad y otra habitación. En 1479, el concejo pagaba 1.000 maravedíes anuales a Isaque Almateri por el alquiler de una casa, en que se alojaba Alfonso de Valladolid, cotomallero. Isaque Javalí tenía su obrador en el cantón de 
Santa Catalina hacia 1485, y algo semejante los hijos de Aben Mismer, e igualmente en el cantón de la sedería tenía casas Salomon Abençar. Los ejemplos son abundantes.

$Y$ al contrario. Los cristianos también eran dueños de casas en la judería. En un pleito iniciado en 1474 fue condenado Abraham Botín e ingresó en la cárcel como fiador que había sido de su suegro Samuel Botín «el gordo», arrendatario de la carnicería, ya difunto, por débito de 20.000 maravedíes al provisor del Obispado. Para liberarlo, y previo consentimiento del provisor, Mayr Botín y Mayr Rocancho aceptaron ser fiadores pagadores, y señalaron las casas que Botín tenía cerca de Abendaño, mayordomo del adelalantado Fajardo y las que Rocancho tenía junto a la "sinagoga chica". El plazo fue breve, mes y medio, pero en el mismo día el provisor vendía tales casas por 20.000 maravedíes al regidor Alfonso Riquelme. Algo semejante sucedió en las casas de Yuçaf Alorí, arrendatario muchos años del cobro de la sisa, quien al morir en 1489 sin dejar bienes, el mayordomo concejil embargó sus casas en tanto no se revisara su arrendamiento y débitos.

Cuando en cumplimiento de los acuerdos de las Cortes de Toledo de 1480 el visitador Juan de la Hoz formó comisión con dos regidores y llevó a cabo una meticulosa delimitación de la judería, fue señalando lugares de separación y abriendo nuevas calles con el mismo objeto. Hoy, en el plano urbano, cabe ubicarla entre las actuales iglesias de Santa Eulalia, San Lorenzo y Merced, ya que su parte septentrional la limitaba la muralla, tal como se confirma con la concesión de torres al zapatero Samuel Azobeb en 1475 y años después a Mayr Abendaño, al que se ayudó con 1.497 maravedíes para arreglo de ella a par de sus casas; igual al cirujano maestre Abraham ante la "asaz estrechura» en que vivía y concesión de una torre de la muralla en 1479 para ensancharla y obtener espacio suficiente para guardar paja y otras cosas ${ }^{2}$.

Juan de la Hoz dejó bien señalado que los judíos no debían tener ningún contacto externo salvo por sus puertas, que desde 1482 a 1492 serían tres, destinadas tras su expulsión para la casa de los carros del Corpus, casa del peso de la harina y para Santa Quiteria ${ }^{3}$. Meses más

\footnotetext{
2 TorRes Fontes, Don Pedro Fajardo, adelantado mayor del reino de Murcia. Madrid 1953, en donde se publican las cartas reales y delimitación de Juan de la Hoz.

3 En 24 de julio se daba orden de poner en venta las puertas de la judería, después de pagar tres reales gastados en su reparación. Antes, el 10 de julio de 1492 se negaba licencia a Rodrigo de Arróniz para aprovecharse del adarve que estaba junto a las casas que compró en la judería. El 15 de septiembre el pesquisidor ordenaba derribar el portal de la judería y se guardaran los ladrillos y cal para obras en la ciudad. El 22 de mayo aún quedaban judíos, porque este día el Procurador del común obtuvo aprobación del concejo en prohibir a la aljama
} 
tarde, el 2 de octubre, el alcalde Lope Alonso de Lorca, cumpliendo la sentencia de Juan de la Hoz y atendiendo la petición de Pedro Ximénez Polvorello mandó hacer ejecución en bienes de los jurados de la aljama en cuenta de 9.000 maravedíes en que se valoraba lo que le habían tomado para «fazer la calle del apartamiento de la judería». Y el 27 de este mes se ordenaba al mismo Pedro Ximénez que derribara una cámara que tenía sobre el apartamiento de los judíos, porque era perjuicios para éstos $y$, al mismo tiempo, se le comunicaba el pago de los 9.000 maravedíes con que se le indemnizaba «el corral» que le habían tomado para abrir calle de separación. Y, al contrario, a los judíos se les daba plazo de seis días para cerrar los "postigos que salle fazia los christianos", con advertencia que de no hacerlo, el concejo lo haría a su costa. El sábado siguiente nuevo aviso y plazo de veinte días para poner puertas a sus nuevos portales. Esta vez la delimitación efectuada con rigor y rapidez separaba dos mundos, a los que se quería diferenciar cada vez más, comienzo por otra parte de una directriz política bien definida ${ }^{4}$.

Por esta documentación sabemos que la judería contaba con sinagoga principal y otra "chica", así como carnicería propia cerca de la muraIla, una de las tres concedidas por Alfonso X en 1266 a la ciudad de Mur$\mathrm{cia}^{5}$. Dos cementerios, uno, el más antiguo, quedaba distante y utilizado en los siglos XIII y XIV, situado cerca de la Puerta Nueva y Torre de las Lavanderas, que en 1492 sería concedido por los Reyes, por mitad, al monasterio de Santa Clara y al regidor Alfonso Fajardo ${ }^{6}$.

que dispusiera de las puertas exteriores y no pudieran venderlas. Hasta el 4 de agosto no se pregonó la carta real prohibiendo a los judios vender la sinagoga, osarios, casas y otras posesiones comunes de la aljama.

4 En junio de 1478 Mose Aburedan obtenía carta real contra vecinos que querían abrir un portillo en casas de su propiedad. La delimitación de Juan de la Hoz ha sido estudiada por Roselló Verger y Cano Garcia, Evolución urbana de la ciudad de Murcia (831-1973). Murcia 1975.

5 ToRRES FonTES, «El recinto urbano de Murcia musulmana», 2. ${ }^{2}$ ed., en Murcia Musulmana. Murcia 1989, págs. 151-197.

${ }_{6}$ En diciembre de 1477 los representantes de la aljama protestaban ante el concejo de la concesión a su escribano Francisco Pérez Beltrán de un pedazo de tierra ante la Puerta Nueva, entre las acequias de Nelva yel camino público que iba al osario de los judíos y el real de Escámez para plantar moreras. Suplicaban a los «padres governadores e administradores de la justiçia e defensores de la republica: que revocasen la donación. Se designó una comisión y los regidores nombrados hicieron cavar «e sacaron guesos dellas». Por ello el concejo expuso que su intención no fue ni era "fazer perjuizio alguno a los judios", por lo que revocaron su acuerdo y considerando como cosa propia de la judería, la dejaron «libre e desenbargada para que la ayan e tengan e posean para ellos e para los que despues dellos vinieren". Al año siguiente, 1478, nueva queja de la aljama, esta vez porque en dicho osario "viejo" se ataban bestias, picaban lino y alli dormía el ganado, convirtiéndolo en estercolero, por lo que pedían lo remediasen. Hubo prohibición concejil de hacer allígarberas de lino, picarlo, llevar ganado, etc. Pregón inútil porque cuatro meses más tarde se repiten las quejas y el nuevo acuerdo 
Un recinto aislado con calles angostas de trazado musulmán que favorecía su seguridad, únicamente reforzada la vigilancia del alguacil en Viernes Santo, que año tras año luchó inútilmente en que se le aumentara la gratificación de 300 maravedíes que se le abonaban. El "circuito" favorecía su cohesión y mantenimiento de sus tradiciones y formas de vida, aunque en la década de los setenta el propósito concejil de embellecer la ciudad se extendió hasta la judería cuando ordenó derribar los bancos que en las calles dificultaban el tránsito, aunque mermaba el trabajo de los artesanos que los utilizaban para sus manufacturas ${ }^{7}$.

Marginación nocturna, pues nadie impidió su directa participación en la vida ciudadana en el transcurso del día, antes que tocara la campana del alguacil, con sus variadas ocupaciones en tiendas, talleres y oficios que no les apartaba de la convivencia y relación con las familias cristianas. Incluso con salidas nocturnas, pues el jurado Diego González de Peñaranda no dudó en denunciarlos, porque además salían con armas; lo que se manifiesta en las repetidas ordenanzas concejiles prohibiendo su salida con excepción de físicos, cirujanos, el sisero y los obligados de las carnicerías, vedado siempre de día y de noche de portar armas, salvo el encargado del reloj, porque el tiempo contaba ya para todos y le convenía ir sobre seguro.

Totalmente sometidos a las decisiones del concejo, aunque siempre con posterior recurso a la Corte en las decisiones concejiles consideradas injustas; protegidos en su vida interna, aunque el almotacen, en ocasiones, tuviera alguna discutida intervención en materias relacionadas con su oficio, tanto en obras como en limpieza; ingerencias indebidas del alguacil, que el concejo reconvenía y limitaba, no perturbaban la vida en el interior de la judería, en la que sus jurados y el rabino ${ }^{8}$ gobernaban, aunque la personalidad de algunos, riquezas de otros y los clanes familiares, no siempre bien avenidos se imponía sobre los demás. La armonía no siempre imperaba en su interior ${ }^{9}$, aunque con escaso eco ex-

concejil penalizaba con $150 \mathrm{mrs}$, a los infractores. Otra vez en 1480 y la pena se elevó a 300 mrs. Cuando en 1492 se hace merced a Alonso Fajardo por mitad con el monasterio de Santa Clara, se menciona el osario y enterramiento mayor de los judíos y orro pedazuelo, también osario, que estaba situado junto a la acequia mayor y cerca la heredad de Diego Ruiz de Murcia.

7 Un recinto no siempre cerrado al exterior, porque el alguacil tenía derecho de entrada para sus rondas, e igualmente se dispuso en 1482 que cuando se trabajara en las almazaras de la judería (actual calle Obispo Frutos) debían estar abiertas las puertas de ella.

8 En 1475 eran jurados Isque Aventuriel, Isaque Botín y Abrahím Abenhaça. En 1478 Isaque Modur, Mayr Abendaño e Isaque Almateri.

9 En 1482 se hallaba preso en la cárcel concejil por orden del corregidor el judío isaque Navarro por negarse a dar los nombres de los judíos que habían querido matarle en la judería, y en que habia recibido heridas en un brazo y sus ropas quedaron destrozadas a cuchilladas. 
terior y en ella en la segunda mitad del siglo xv se mantenía cierto equilibrio por la preponderancia de cuatro o cinco familias; muchos en estrecha relación económica con el alto clero y nobleza y conjuntados en diversos negocios; otros imponiéndose en la recaudación de tributos reales y concejiles, aunque no siempre continuados, ya que la competencia degeneraba, a veces, en enfrentamientos poco encubiertos, como era la puja en los concursos para la adjudicación de ciertas rentas. Los Aventuriel, siempre numerosos y poderosos; los Abenaex, Cohen, Aben Alfahar, Abendaño y otros con menor protagonismo aparente, son los que personalizan actos diversos y los que más mencionados encontramos en las actas concejiles o capitulares. Desde 1473 se exigió la vecindad con fianza y mínima de cinco años, bajo pena de ser devueltos a su lugar de origen y 5.000 maravedíes de multa.

\section{LA VISITA DE JUAN DE LA HOZ}

En cumplimiento de los acuerdos de las Cortes de Toledo de 1480, al regidor segoviano le correspondió desplazarse al reino de Murcia y hacer cumplir las instrucciones que le dieron: delimitación de la judería con prohibición a los judíos de tener vivienda fuera de ella; distinción pública de su condición con señales bien visibles y revisión de las cuentas concejiles y, sobre todo, de las recaudaciones; aparte otras decisiones de carácter secundario, como el estado de la muralla, defensa de la ciudad y seguridad del reino.

La delimitación de la judería se realizó con minuciosidad para su mayor efectividad, cierre de calles, apertura de otras para aislarlas y fijando tres puertas exteriores. Su resolución, aunque rigurosa, puede considerarse beneficiosa para la vecindad judía, toda vez que aceptaba la realidad, lo cual suponía considerable ampliación del «circuito antiguo», con lo que daba cabida a un número indeterminado de casas adquiridas en el transcurso del tiempo por distintos judíos, entre los que se encontraban varios de los más destacados miembros de la judería, casi duplicar su primera extensión, aunque los gastos de la reforma y ampliación fueran a costa de los judíos beneficiados.

Mayor trascendencia pudo tener su ordenación para que se cerraran las tiendas que tenían abiertas en la ciudad, especialmente en la plaza

Su negativa a dar nombres, era, según manifestaba, porque su religión se lo prohibía, había sido la causa de su detención (TORRES FONTES, «La ley del silencio», en Estampas medievales, págs. 470-473). 
de Santa Catalina y sus aledaños, como lugares más céntricos y concurridos. No queda anotación oficial por parte del concejo de que se hiciera efectiva, pues por lo que parece como tantas otras semejantes sería obedecida pero no cumplida ${ }^{10}$.

Derivada de esta «Visita» fue el acuerdo concejil de 12 de diciembre, pregonado al día siguiente respecto a la obligación - tantas veces repetida en el correr de los años- de llevar «roldetes de paño colorado en los pechos, en la parte de la izquierda, en manera que claramente se muestre e parescan a todos", con la advertencia de no encubrirlas u ocultarlas, con penalización a los contraventores de pérdida de la «vestidura más exterior» la primera vez, agravada la segunda con veinte días de cárcel y a la tercera se sumaba destierro por un año; dentro de la judería desaparecería esta obligación.

El concejo cumplía las órdenes reales, pero en el mismo día otro pregón hacía público que ningún vecino de cualquier estado o condición, no fuera osado decir o hacer alguna manifestación referente a dichas señales y a quienes las portaban que pudiera resultar injuriosa $u$ ofensiva o les acarreara algún daño, apercibidos de ser condenados a veinte días en la cadena y correspondiente multa.

En igual sentido se extendía esta disposición y pregón para los moros, pero con mayor trascendencia, pues se solicitó a los Reyes que pusieran fin al menosprecio, inconvenientes e injurias que representaba el que "canten el çala a bozes en sus torres de sus mezquitas», pero la prohibición que pedían era que fuera general desde Játiva a Murcia, porque si sólo se hacía en esta ciudad, donde entonces habitaban menos de veinte familias, se irían donde no les fuera vedado y la morería quedaría despoblada.

También la visita de Juan de la Hoz incidió en otro aspecto, con antecedentes variados. La relación cristiano-moro-judío fue siempre pacífica, inequívoca y diferenciada; hubo aspectos prohibidos como el de moro o judíos con cristiana, castigado con la máxima pena e incluso, aunque en menor grado, el de tener a cristiana como esclava. Así sucedió en el caso de Mose Cohen, con largo y controvertido pleito al ser denunciado de tener «por esclava una christiana diziendo era mora, lo qual es en gran mengua e ynjuria de nuestra santa fe catolica». Tras muchos sinsabores, detención, embargos y fianzas, Mose Cohen pudo demostrar la falsedad de cuanto se le había imputado y quedó libre de toda sospecha ${ }^{11}$.

10 Torres Fontes, «La visita de Juan de la Hoz», en Estampas medievales, págs. $452-455$

11 TORRES FONTES, «Los judíos y sus esclavos», en Estampas medievales, págs. 481-486. 
No fue esto sólo, porque acabó también siendo inaceptable para los cristianos la continuidad de los judíos con esclavos moros, pues desde mediados del siglo $\mathrm{xv}$ comienza a manifestarse cierta inquietud cada vez más agresiva, porque no era sólo la simple presunción de que alguno fuera cristiano, ya que tal situación no sería permitida, sino tener esclavos. Las causas no se especifican por entero, aunque uno de los aspectos se relacionaba con la necesidad de sus servicios; otra de las razones alegadas públicamente fue la que los esclavos moros «en poder de los dichos judios toman grand osadia e atrevimiento por la mucha soltura que les dan", tal como se pregonó el 14 de febrero de 1475. Lo cual tiene relación con la decisión concejil, prohibiendo que esclavos y esclavas de los judíos fueran autorizados a estar en casa de cristianos ni anduvieran con ellos ni con sus cautivos los sábados, días de Pascuas y otras festividades. $Y$ más de una vez se denuncia que «los esclavos que hay en esta çibdad son muy grandes ladrones..., grandes furtos». En 1478, se les castigaba públicamente con 100 azotes y muchos de ellos blasfemaban para pasarse treinta días de cárcel «por estarse holgando».

Ofensiva adelante, ya que por parte concejil se prohibió a los judíos comprar moros cautivos o tenerlos en sus casas, aunque se les permitiera poder compartir su propiedad con cristianos, pero siempre bajo la responsabilidad de éstos. Y una tercera fase fue en 1479 cuando se solicitó a los Reyes Católicos que dispusieran que los judíos no tuvieran o compraran esclavos blancos o negros, salvo menores de quince años, y si los tenían de edad superior fueran obligados a venderlos o a compartirlos con cristianos y en poder de éstos.

La estancia de Juan de la Hoz propiciaría la exposición de quejas y agravios. Y una de éstas fue en 1481 al denunciar los vecinos «los exeas judios que tratan e comunican mucho con los moros en su regno, conosçen e saben quien es cada uno e lo que valen, de manera que por el dicho aviso, todos los moros vienen en poder de los dichos judios". Lo que se explica en esta denuncia es previo conocimiento de los judíos, cuáles eran los moros que podrían rescartarse y su valor, así como los que seguirian esclavos, por lo que se quedaban con los mejores y más valiosos, en perjuicio de los cristianos, que recibían los que ellos no querían, muchos de los cuales "pereçen en el cautiverio". La resolución fue que los judíos no pudieran comprar ni tener esclavos moros, y los que entonces tenían y no los quisieran vender, los mantuvieran en propiedad compartida con cristianos y no en su poder ni para su servicio. Medidas cada vez más restringidas, pero con una nueva excepción, la de que 
pudieran tener esclavos propios pero exclusivamente negros de Guinea y nunca blancos ${ }^{12}$.

Otra cuestión que encontró solución, por entonces, fue la insistencia concejil de obligar a los judíos cuantiosos a mantener caballo y armas. El auge que por algún tiempo tuvo la caballería popular, tan necesaria siempre, hasta que la conveniencia de poder contar con ella para la seguridad de la frontera granadina motivó que Alfonso XI la hiciera obligatoria; pero la medida estaba ocasionada por la disminución de su número a causa del mayor coste que implicaba mantener caballo y las armas correspondientes que la franquicia que reportaba, aunque hubo sus excepciones. La inestabilidad de la frontera hizo que se extremaran las exigencias en los reinos murciano y andaluces; en principio, tanto por su condición social y religiosa, judíos y moros no fueron considerados aptos para integrarse en la hueste militar, incluso Alfonso XI y Enrique II en sus ordenamientos especificaban «qualquier judio que non oviese mas de vna bestia, que la pueda traher sin traher cavallo, e sy oviere de traher compañero, que se de mula; e sy toviere dos mulas, que tenga cavallo".

En 1445, a consecuencia de la guerra civil que afectó a todo el reino de Murcia y de la indefensión en que quedó la frontera, dio lugar a que algunos regidores y el corregidor Alfonso Díaz de Montalvo propusieran la inclusión de los judíos en la caballería de alarde, a igual que los cristianos que tuvieran cuantía de bienes superior a la cantidad señalada por los Reyes. No parece que esta decisión concejil estuviera motivada por una actitud antijudía. La prestigiosa figura de un jurista tan notable como Díaz de Montalvo no encontró disposición legal en contrario, más aún por cuanto consideraba que todos los habitantes del reino y, en este caso, los de la capital, debían cooperar en la medida de sus posibilidades económicas en la defensa del territorio que a todos afectaba. De aquí que en este mismo año 1445 fueran incluidos en el padrón de la collación de San Lorenzo, la más cercana a la judería, Mose Çaban, Abrahim Chereça, Isaque Cohen y Samuel Abenarro/o. No vuelven a ser mencionados los judíos en los alardes de los meses siguientes. La causa debió ser la negativa real, o el cambio de corregidor, aunque cabe explicarlo por un acuerdo concejil, ya que prohibieron a los judíos ausentarse de la ciudad con sus bienes, pues les aseguraban personas y haciendas.

\footnotetext{
12 No fueron sustituidos los alfaqueques judíos, siempre los más adecuados para este trabajoso y delicado oficio, con frecuencia expuesto a vejaciones, pérdidas económicas en una misión no fácil para convenir y efectuar rescates, fijar precios, dar fianzas, evitar engaños, localizar cautivos, etc., además de ofrecer valiosos informes de la situación política y económica del reino granadino. Así lo fue Aben Crespo en los primeros años de este reinado, y también Gabriel Israel, nombrado en 1476, pero con diversidad de actividades.
} 
Vuelven a repetirse estas pretensiones en el reinado de Enrique IV. En 1457 , el concejo aceptaba la propuesta de un regidor para que se obligara a los judíos cuantiosos a mantener caballo. No lo hicieron en el alarde de marzo, pero se hizo constar los nombres de 42 vecinos que debían haberlo hecho, y entre ellos los de 16 judíos, bien conocidos por su actividad y potencia económica, en su mayor parte recaudadores de rentas reales y concejiles e incluso dos físicos. No tendría efectividad. Dos años más tarde volvieron a insistir algunos regidores y de tal forma apremiaban, que los judíos recurrieron a Enrique IV, quien en carta de 28 de enero de 1460 se opuso, haciendo constar que en Andalucía y Murcia no se había dado tal caso, ya que los judíos alegaban que por sus oficios, educación y modos de vida no eran aptos para el servicio de armas ni podían ser útiles para lo que se les apremiaba, aparte que pagaban iguales tributos que los cristianos y además cabeza de pecho; tampoco costear caballo, armas y jinete, pues sería un gravamen imposible de sostener. La negativa de Enrique IV fue suficiente para abandonar tal propósito, que renace en 1472 cuando ante la escasez de caballeros de alarde, el concejo encargó a su escribano que se informara quiénes entre judíos y moros, incluso los de Alcantarilla vasallos de la Iglesia, eran abonados para mantener caballo.

Nueva petición en tiempos difíciles y decisivos para los Reyes Católicos por la rebelión nobiliaria y la intromisión portuguesa en la guerra de sucesióri. Los monarcas aceptaron la solicitud murciana y en marzo de 1475 lo hicieron obligatorio a todos cuantos tuvieran cuantía superior a 30.000 maravedíes. No encontramos a judío alguno en los semestres siguientes en las relaciones de los alardes, quizá porque en el mismo año fue elevada la cuantía obligatoria a 50.000 maravedíes; pero también hay que tener en consideración que los Reyes facilitaban solución, el que los judíos con bienes superiores a esta cifra, vendieran sus heredamientos y fueran los compradores quienes cumplieran esta obligación. No vuelve a hablarse ni mencionarse en las relaciones de los alardes a judío alguno ${ }^{13}$.

Negativa o protesta cada vez que se les exigía prestación armada, que en ocasiones suplieron con el pago del coste correspondiente. Cuando el temor se extendió por todo el reino de Murcia, después de la incursión de Abul Hasán y cautiverio de la población de Cieza, la amenaza de su posible vuelta obligó a la movilización general y adopción de medidas extremas de seguridad. Los judíos protestaron de la cuota que se les había

13 ToRrES FONTES, "La incorporación a la caballería de los judíos murcianos en el siglo XV", Murgetana, n. 27. Murcia 1966, págs. 5-14. 
asignado y lograron que se rebajara su contribución a 30 espingarderos para vigilancia de la muralla.

\section{LA INQUISICIÓN}

Las decisiones políticas, y más aún cuando eran de carácter trascendente, solían responder a causas o motivos generales que forzaban a adoptar medidas adecuadas por impopulares que entonces pudieran serlo. Lo fue la Inquisición, impuesta por circunstancias político-religiosas que sólo pudieron contentar y parecer convincentes a un número no muy grande, por cuantas repercusiones tenía o se decía tener, toda vez que su implantación gradual daría lugar a que las noticias de carácter negativo o de supuesta amenaza, para algunos, se propagaran con mayor rapidez que las realmente efectivas a no ser, como sucedió con las conquistas castellanas en el reino de Granada, que se comunicaban incluso en el mismo día en que tenía lugar su ocupación. Por otra parte, la retransmisión de ciertas noticias acababan transformándose en verdades deformadas y los rumores se convertían en testimonios, con lo que la realidad de los hechos no siempre afloraba con la veracidad requerida.

¿Cuándo y cómo llegó la Inquisición a Murcia? Fue tardía y respondió a la aplicación de una medida de carácter general que paulatinamente se extendería por todos los obispados castellanos, y no había razón alguna en contrario para que el de Cartagena quedara exento. Por lo que sucedió en Murcia no es aventurado deducir que hubo propósito de implantación bastante anterior a cuando tuvo lugar y se retrasó por la oposición del concejo murciano, en un acuerdo adoptado por unanimidad y que respondía a una política tradicional en defensa de todos sus vecinos, sin distinción de raza o religión ${ }^{14}$; no hubo ni se produjo muestra alguna de manifestaciones públicas u oficiales de descontento, de inseguridad o preocupación por la paz ciudadana de cuantos en ella vivían ${ }^{15}$.

14 Torres Fontes, «Riesgo de Izag Cohen y ventura de Alfonso Yáñez Cohen», en España Medieval. Estudios en memoria de Salvador de Moxó. Madrid 1982, II, págs. 653-664.

15 Pese al "oasis" de paz que siempre representó Murcia para los judíos, no faltaron o se produjo algún incidente antijudío o anticonverso. Fue así en el reinado de Enrique $I I I$, y remito a "Los judíos murcianos a fines del siglo xIV y comienzos del XV", M.M.M., n. ${ }^{\circ}$ VIII. Murcia 1981 , págs. 57-116; en la regencia de don Fernando de Antequera, «Moros, judíos y conversos en la regencia de don Fernando de Antequera", Cuadernos de Historia de España. Buenos Aires 1960, págs. 60-97; en el reinado de Juan II, "Los judíos murcianos en el reinado de Juan II, Murgetana, n. ${ }^{\circ}$ 24. Murcia 1965, págs. 5-33; o en el de Enrique IV, «La propagación de las predicaciones de fray Alonso de Espina (1461)», en Estampas, págs. 449-451. 
En la documentación murciana de estas dos décadas, fundamentalmente en las actas concejiles, eco del vivir cotidiano de la ciudad, aunque sólo fuera de carácter oficial, no encontramos mención alguna respecto a posibles inquietudes religiosas, fuera de las repetidas advertencias referentes al paso de las procesiones, especialmente la del Corpus y el guardar las fiestas. Relación cristiano-judío en todo tiempo comprensiva, sin que causas diversas, derivadas siempre del factor económico, rompieran una línea continuada e inquebrantable de convivencia. Tampoco conocemos hechos que ocasionaran enfrentamientos entre judíos y conversos, ni que se produjeran actos hostiles entre unos y otros, salvo la tenaz pugna mantenida entre el recaudador David Aben Alfahar y el jurado Juan de Córdoba. Los conversos, por lo menos oficialmente, se relacionaban más con los cristianos viejos que con los judíos y cuando surge la discordia es siempre también por motivos económicos. Y en este contacto y trato cristianos viejos y nuevos cabe destacar las inquietudes culturales de algunos de ellos, como fue el jurado Juan de Córdoba, que perdería su oficio por haber sido condenada su madre por la Inquisición, al que vemos integrado en el círculo cultural que se reunía en torno de Diego Rodríguez de Almela, y al cual el canónigo historiador dedicaría uno de sus estudios o tratados ${ }^{16}$. Y en el tercer aspecto de esta relación ciudadana es concluyente la mantenida por judíos y alta clerecía, estrechamente unidos en diversos asuntos económicos, que sobrepasaban en mucho la de recaudación de los diezmos, pues las abundantes muestras de los pleitos mantenidos ante el vicario general de la diócesis es bien significativa. Como tambiénn lo fueron las relaciones y atenciones del adelantado Pedro Fajardo y su esposa Leonor Manrique.

Coexistencia no tan difícil como sin mucha consistencia se ha dicho y, en cambio, sí comprensión amplia, tal como se manifestaría cuando surgió lo imprevisto para la mayor parte de los castellanos, la Inquisición y con ella apertura para oportunistas, rencorosos y envidiosos, en donde el miedo y la venganza, la debilidad y la ignorancia, enfermedades y apasionamientos se dieron cita con excesiva frecuencia. De inmediato un genovés de contradictorias actuaciones, Baltasar Rey, un mercader poco escrupuloso y conducta un tanto desordenada, interesado en negocios

16 Torres Fontes, La compilación de los milagros de Santiago de Diego Rodríguez de Almela. Murcia 1956, págs. XLII y XXIX. En el mismo círculo cultural, relación con Almela y Juan de Córdoba, que también obtuvo la dedicatoria de uno de los tratados de Rodríguez de Almela, se hallaba el comendador santiaguista Fernando de Pineda, visitador de la Orden, quizá con parentesco con otro comendador santiaguista Juan de Pineda, de cuyas andanzas y final en la hoguera por judaizante nos ilustra YITZHAK BAER en su Historia de los judíos en la España cristiana, Il. Madrid 1981, pág. 399. 
muy aiversos que le ocasionarían disgustos, peligro de muerte y malquerencia general, asociado y disociado de grupos familiares y de otros compañeros en actividades mercantiles, iba a protagonizar la primera denuncia contra judíos y conversos. Antes, en 1483, había denunciado a Yuçé Axaques, arrendador de la Hermandad, porque le apremiaba al pago de lo que se le había asignado, y el concejo confirmó las exigencias tributarias del recaudador. Mantenía estrechas relaciones cortesanas y en ella con Clara Albarnaez, madre del adelantado Juan Chacón y camarera de la reina Isabel. Merced a ella consiguió carta real, por la que se le concedia naturaleza castellana ${ }^{17}$.

Fue Baltasar Rey quien presentó en la Corte escrito denunciando ocultas relaciones religiosas entre conversos y judíos. Lo cual pronto se supo en Murcia y los más destacados representantes de la judería: David Aben Alfahar, maestre Isaque Aventuriel, David Aventuriel, Abrahim Aventuriel y Yuçé Allorí, acudieron ante el concejo para expresar su inquietud y protesta por el alcance y consecuencias que pudiera tener tal acusación, ya que temían que a "capsa de lo qual sus altezas enbian a esta çibdad sus ynquisidores", por lo que solicitaban a los regidores su pronta intervención y ayuda. En su exposición, los representantes de la aljama hacian constar que ante tanta malicia y mala voluntad del genovés, pedían su comprensión y escrito a la Corte, pues a ellos era bien conocida cuál era la vida de unos y otros, ya que tanto los "conversos heran buenos christianos", como los judíos en la conservación de su ley, que guardaban con buena compostura y costumbres. $Y$ en su petición insistían que rechazaran la acusación de Baltasar Rey e hicieran constar a los Reyes la pacífica convivencia y la normal práctica de su religión por cada uno de ellos.

Hubo unanimidad concejil, pues a todos los regidores era cierto cuanto decían los representantes de la aljama y la falsedad de la denuncia de Baltasar Rey, por lo que acordaron escribir a los Reyes para que tuvieran conocimiento de la verdad y su rechazo a cuanto había expuesto el mercader genovés.

Por otra parte, el 21 de enero de 1486 se enviaba carta al Prior de Santa Cruz para manifestarle que la ciudad de Murcia estaba limpia de malos cristianos y no consideraban necesario el envío de inquisidores, si bien, añadían «que si su merçed entiende que los deve enbiar, que se faga». Una semana más tarde volvían a escribir al Prior de Santa Cruz - si no era la misma carta rectificada y ampliada -, para informarle que

17 ToRres FonTES, «Genoveses en Murcia (siglo xv)», M.M.M, II. Murcia 1976, págs. 71-168. La queja en 13-III-1484, pág. 161 y carta de naturaleza, 16-III-1485 en págs. 162-164. 
en Orihuela sí había malos cristianos, en tanto que en Murcia estaba limpia de ellos, y si los Reyes decidían implantar la Inquisición en el obispado, que fuera en buena hora para que se conociese la verdad de cuanto declaraban. La afirmación concejil resultaba un tanto singular, pues si Orihuela se hallaba incluida en el orden eclesiástico en la diócesis de Cartagena, era ciudad realenga de la Corona de Aragón.

Razones que debieron pesar, puesto que no es hasta 29 de mayo de 1488 , cuando los Reyes se hallaban precisamente en Murcia, firmaban su carta comunicando el nombramiento de Sancho de Calancha y de González del Fresno como Inquisidores de Murcia, quienes se presentaban en la ciudad el 9 de junio de este mismo año ${ }^{18}$.

\section{FISCALIDAD}

La variedad de impuestos que entre 1475-1492 regularmente debían pagar los judíos a la Hacienda real, Concejo e Iglesia, se incrementaba con diversas contribuciones que los regidores imponían a todos los vecinos para atender variedad de necesidades, las cuales unas veces afectaban a la aljama y otras singularmente a determinadas personas por los bienes que poseían. No desaparecieron antiguos tributos pese a su desfasada cuantía, como cabeza de pecho al rey o los 30 dineros a la Iglesia, sino que se incrementaron con otros nuevos, como los llamados castellanos de oro que en cierta manera equiparaba a los judíos con la Hermandad que pagaban los cristianos, si bien, ante la continuidad de la guerra de Granada y cuanto suponía la carga tributaria que soportaban los pecheros, el concejo intentó y acabó consiguiendo incluir a moros y judíos en los consiguientes repartos.

Otro aspecto, también poco conocido y que por ello ha dado lugar a diversidad de interpretaciones, fue la participación judía en el arrendamiento y recaudación de rentas reales y concejiles. Sin intentar aprovechar cuanto las fuentes documentales ofrecen, lo que hemos recogido muestra suficientemente cual fue la intervención de los judíos tan mayoritaria hasta última hora, que no significa un caso insólito. Agregamos igualmente un epígrafe del arrendamiento de la carnicería, porque los estudios realizados y la documentación existente permiten ampliar la nónima con semejante perspectiva de la preponderancia judía al frente de ella. Faltan los documentos, que desafortunadamente sólo llegan hasta 1474, referentes a

18 Torres Fontes, Estampas medievales, págs. 506-513. 
la cooperación judía con el Cabildo catedralicio hasta 1486, en que hubo acuerdo de prescindir de sus servicios, pero por lo que conocemos de los años anteriores, la conjunción de los judíos con el alto clero catedralicio fue intensa y extensa.

\section{CABEZA DE PECHO, SERVICIO Y MEDIO SERVICIO}

La primera recaudación de los tributos específicos que los judíos pagaban al rey no está documentada hasta 31 de mayo de 1437, aunque Ladero ${ }^{19}$ deduce, por su contenido, que pudo iniciarse en el reinado de Enrique IIII, en que ya de forma concreta se conjuntan la contribución que judíos y moros pagaban directamente a su soberano: cabeza de pecho, servicio y medio servicio, esto es, prestación económica personal o capacitación y general por aljamas, distribuidas igualmente por el número de vecinos que tenía cada una de ellas. La primera, la más antigua, obligaba, según Amador de los Ríos $^{20}$ a cada cabeza de familia al pago anual de 45 maravedíes, y la segunda en su doble concepto de servicio y medio servicio era una cantidad global sobre los judíos castellanos que, como en 1474, Rabí Aben Núñez como «juez mayor e repartidor de los servicios e medios servicios» distribuía entre todas las aljamas del reino y que comunicaba a los tesoreros reales para que pudieran llevar a cabo su recaudación.

Contribución que les eximía de algunos impuestos concejiles que recaían sólo sobre la población pechera, ya que así oficialmente quedaban bajo la directa dependencia del monarca, que por su parte les proporcionaba su amparo, seguro y protección. Aportación anual, no siempre la misma, aunque las variantes fueron escasas en el transcurso de los años, y por lo que parece tributación superior a los pecheros cristianos, pero no, por ello, dejaba de ser un seguro conveniente y acogedor, por lo que mantuvieron tenaz defensa en conservarlos, pues les liberaba oficialmente de las desmesuradas y equívocas derramas que los concejos podían imponer en cualquier tiempo y por cualquer causa; más aún por cuanto las contribuciones no serían iguales en todas las aljamas y, además se hubiera debilitado el nexo que les unía en la persona del juez o rabí mayor. Los Reyes Católicos confirmaban el 27 de

19 Ladero Quesada, Miguel Ángel, «Los judíos castellanos del siglo XV en el arrendamiento de impuestos reales", Cuadernos de Historia, VI. Madrid 1975, págs. 417-439. "Las juderiás de Castilla según algunos "servicios" fiscales del siglo XV", Sefarad, XXXI, Madrid 1971, pág. 263. El servicio y medio servicio de Murcia en 1474 fue de 8.500 maravedís y 6.000 en 1479 . Añade a Mula con 200 y 500 respectivamente.

20 AmAdor DE los Ríos, J., Historia social, política y religiosa de los judíos de España y Portugal. Madrid 1960, pág. 996. 
octubre de 1477 carta de Juan II de 1437, confirmada por el mismo monarca en 1447 y 1453, prohibiendo que se incluyera a los judíos en las derramas concejiles, empréstitos y pago de gente de guerra, pues ya contribuían con cabeza de pecho, servicio y medio servicio "como en otras neçesidades que se les recreçen»" ${ }^{2 \uparrow}$.

\section{La contribución murciana fue la siguiente:}

1465-1474. Cabeza del pecho judío ${ }^{22}$, servicio y medio servicio de judíos y moros de la ciudad de Murcia, cada año

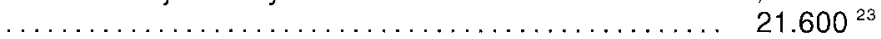

$\begin{array}{llll}1475^{24} & & 1481 & 6.000^{27} \\ 1476^{25} & & 1482 & 26.000 \\ 1478^{26} & 17.500 & 1483 & 26.000^{28} \\ 1479 & 17.500 & 1489^{29} & \\ 1480 & 26.000 & & \end{array}$

21 Los Reyes Católicos confirmaban el 27 de octubre de 1477 carta de Juan II, confirmada a su vez por el propio monarca en 1447 y 1453 prohibiendo que se incluyera a los judíos en las derramas concejiles, empréstitos y pago de gente de guerra, pues ya tributaban cabeza de pecho, servicio y medio servicio "como en otras necesidades que se les recreçen» (SUÁREZ, Luis, Documentos acerca de la expulsión de los judios. Valladolid 1964, págs. 125-130).

${ }^{22}$ Cabeza de pecho judíos, en tanto que servicio y medio servicio de moros y judíos.

23 Finiquito por estos diez años otorgados por los Reyes Católicos al adelantado Pedro Fajardo en Medina del Campo, 18-V-1475 (Torres FonTEs, Don Pedro Fajardo, adelantado mayor ciel reino de Murcia. Madrid 1953, págs. 245-262). En el reparto del servicio y medio servicio de 1474, efectuado por Jacob Aben Núñez (Suárez, 69) se asignan a Murcia 8.500. La diferencia hasta los 21.600 del total, comprendía servicio y medio servicio de los moros, así como cabeza de pecho de ambas minorías, pues aunque en el finiquito no se dice nada más que cabeza de pecho judío, en 1475 se incluyen los dos. Lo mismo sucede en los 9.000 de 1482 respecto a los 26.000 del total.

${ }^{24}$ El 3 de mayo de 1475, en el arrendamiento a don David Aben Alfahar de alcabalas, tercias, servicios, etc., se incluye cabeza de pecho de judíos y moros.

${ }_{25}$ En Jerez, 15-X-1476, Pedro de Valladolid, criado de la reina y receptor del servicio y medio servicio y cabeza de pecho judío, otorgaba poder a Alvar Vázquez de Portillo, vecino de Segovia, criado de la reina, para su recaudación.

${ }_{26}$ En la denuncia presentada ante el concejo el 26 de mayo de 1478 por orden del recaudador Fernando de Alcalá por haber encontrado fuera de la cárcel a ciertos judíos detenidos porque debían dinero a los Reyes, amenazaba si no volvían a la prisión, cobrar de bienes concejiles «todos los maravedis que aquellos deven de la cabeça del pecho..." Ladero, op. cit., "Las juderías..." pág. 263 señala que el servicio y medio servicio de Murcia en el año 1479 fue de 6.000 maravedies, con baja de 2.500 respecto al año 1474 .

27 «Porque lo que de mas valio el dicho año se libro en las aljamas a Juan de la $\mathrm{Hoz}$, nuestro pesquisidor que fue por nuestro mandato a la çibdad de Murçia,"

${ }_{28}$ Reyes Católicos. Finiquito de sus Contadores mayores a David Aben Alfahar, su arrendador y recaudador mayor de alcabalas, tercias, almojarifazgo, diezmo de Aragón, serviçio y montazgo, diezmo y medio diezmo de lo morisco, servicio y medio servicio y cabeza de pecho de judios y moros, de los años 1478-1483.

29 Seguian pagando cabeza de pecho los judíos este año, así lo declaraban ante el concejo Mose Alfahar, Abraham Andanel, Jato Abalanchi, Zuleman Abenxuxen e Isaque Aben-Arroyo el 19-1-89. 


\section{CASTELLANOS}

La guerra, siempre cara e innovadora, afectaría a todos los castellanos y la decisión de los Reyes Católicos de mantenerla hasta la conquista total del reino de Granada, sin las seculares detenciones por la concesión de treguas de mayor o menor alcance, forzó a exigir prestaciones extraordinarias. No hubo excepciones de hombres - aunque cada uno enrolado según su condición social y económica- porque todos fueron afectados, aunque tampoco por igual, ya que en los territorios limítrofes al reino de Granada su repercusión sería mayor.

De esta necesidad surgió el nuevo tributo de castellanos impuesto a las aljamas judías castellanas en 1482. Contribución anual que recaída sobre personas con bienes propios y que a partir de 1486 un tercio recaía sobre la capacidad económica de los afectados y dos tercios por cabezas. No conocemos con exactitud la aportación murciana, si bien los datos facilitados por los estudios de Suárez y Ladero ${ }^{30}$ permiten conocer la cuantía de los años 1485, 1488 y 1490, en que puede apreciarse la considerable baja que hubo de efectuarse en estas prestaciones obligatorias a tener de un mejor conocimiento de las posibilidades humanas y económicas de la aljama murciana:

\begin{tabular}{lrrrr}
\hline & \multicolumn{1}{c}{1485} & \multicolumn{1}{c}{1488} & \multicolumn{1}{c}{1490} & \multicolumn{1}{c}{$1490^{31}$} \\
\hline Castellanos & 18.000 & 10.000 & 10.000 & 10.000 \\
En maravedíes & 8.730 .000 & 4.850 .000 & 4.850 .000 & 4.850 .000 \\
Aljama de Murcia & $163.930(1,87 \%)$ & $83.200(1,71 \%)$ & $69.610(1,43 \%)$ & $69.610(1,43 \%)$ \\
Personas & 338 & $171(57-114)$ & $143(47-96)$ & $143(47-96)$ \\
\hline
\end{tabular}

\section{OTRAS APORTACIONES ECONÓMICAS}

No es posible cuantificar las cantidades que, por motivos muy diversos, tuvieron que pagar las aljamas e individualmente sus vecinos, toda vez que no siempre se registraban en los acuerdos concejiles y sólo contamos con un año de cuentas del mayordomo. Resulta así una incompleta muestra de algunas de las contribuciones que hemos podido registrar en esta

SUÁREZ Y LADERO, obs. cits.

Igual aportación para cooperar en el rescate de los judíos cautivados en Málaga. 
relación concejo-aljama, siempre bien entendida y sólo endurecida en algún momento al obligarles a satisfacer sus demandas económicas. Pero siempre teniendo en cuenta que, salvo excepciones propias del convivir ciudadano, éstas exigencias concejiles se hicieron apremiantes por la continuidad de la guerra de Granada, aumentadas desde 1488 al iniciarse la ofensiva castellana desde territorio murciano y cuanto supuso el largo cerco de Baza en 1489 y sus consecuencias.

No fue sólo la contribución económica directa, pues en 1479 al exigir el adelantado 100 peones, en el reparto consiguiente para abonar sueldos, a la judería correspondieron seis y a la morería uno, cuyo importe hubieron de pagar. Lo mismo en 1486, en otra derrama concejil, aparte de la Hermandad, para pago de peones enviados al frente granadino y que afectó a todos los vecinos, sin exclusión, a la aljama se le impuso 5.000 maravedíes, y atendiendo sus reclamaciones, los regidores la disminuyeron a 4.000 .

Debieron ser bastantes más; la última lo fue en enero de 1492 con el envío de 350 peones y 20 lanzas a la entrega de la ciudad y reino de Granada, por lo que se efectuó una derrama de 10 por millar, que les afectó en 50.000 maravedíes al cifrarse sus bienes en 5.000.000. No consta que se hiciera efectiva, pues por lo adelantado de la fecha y cercanía a 31 de marzo, más la consiguiente dilatación que estas operaciones económicas llevaban consigo y más aún los judíos oportunamente presentando sus recursos, es posible su impago, aunque sí contribuyeron por vía de la Hermandad.

Otras veces la deficitaria Hacienda concejil para hacer frente a necesidades perentorias, buscaba, para atenderlas, a todos los medios posibles a su alcance, pues forzosamente eran pagos a cumplir. Unas veces se solucionaba pidiendo a los recaudadores cantidades por adelantado o adjudicando algunas rentas antes de las fechas acostumbradas, y las perentorias recurriendo a préstamos forzosos sin interés.

Fue así en 1491 al cifrarse las deudas pendientes en 175.000 maravedíes, que con urgencia debían abonarse y correspondientes 160.000 a sueldo de peones y 15.000 pendientes de la Hermandad. Siete vecinos cristianos prestaron 11.000; los judíos afectados fueron 21 con el adelanto de 57.000 maravedíes, en que cabe señalar que si las asignaciones fueron de $1.000,2.000$ y 3.000 , a Cohen "el rico" le impusieron 10.000 , a su hijo 2.000 y Abrahim Cohen 5.000; también que ocho de estos vecinos eran de la familia Aventuriel y los restantes casi todos arrendadores y recaudadores.

Préstamo también obligado el de marzo de 1485, en que participaron con elevadas cantidades Cabildo y Vicario, para la adquisición de trigo 
en Valencia. La aportación judía ofrece la peculiaridad de entregar objetos de plata o paños en peños como medio de no perder el interés que podía producir un dinero que tardarían en recobrar. Si Yuçaf Abenaçan prometió 2.000 maravedíes, Ysaque Abenarroyo entregó unas manillas de oro, que dejó en prenda de 1.550 maravedíes, las cuales se las quedó el alcalde, quien hizo entrega de dicha cantidad. Por su parte, Alfatex y Abenacox presentaron dos tazas de plata que valoraban en 3.500 , pero fueron contabilizadas por 2.000. Samuel Cohen prometió 5.000 y David Abenaex 2.000 , entregando en prenda medio salero y cinco cucharas de plata, que también tomó el alcalde y entregó el dinero. Por su parte, Abrahim Aventuriel aportó una pieza de paño verde oscuro seseño en prenda de 2.000 maravedíes.

También de carácter general, y no nueva, fue la derrama echada para el reparo de los adarves, que afectaba directamente a la judería, por cuanto parte de ella la limitaba, y se impuso 30 maravedíes por casa, por lo que se le asignaron 5.000 al cifrar el número de vecinos en 175; la consiguiente protesta fue atendida, por lo que al reducir el número de vecinos a 150, su pago se redujo a 4.500 maravedíes. El arreglo de la torre de Los Alcázares, defensa del camino del Mediterráneo, común a todos, los judíos contribuyeron con 5.000 maravedíes en 1478. De carácter individual como los 5.000 prestados por Zalmati para el pago pendiente de la Hermandad; los 1.000 que prestó el carnicero Ysaque Aventuriel para sufragar el viaje de un regidor a Cuenca; el mismo Aventuriel con 1.140 para envío de guardas a Carrascoy en 1477, recién el asalto a Cieza de Abul Hasan, - 90 para el portador de una carta de aviso. Los ejemplos podían multiplicarse. Otra forzosa contribución era el costear algunos de los toros que se agarrochaban para conmemorar un triunfo militar (Málaga), el nacimiento del príncipe don Juan: seis toros, tres el concejo, dos la judería y uno la morería.

Peculiar en Murcia era el arreglo de la Contraparada o azud divisorio de donde nacen las dos acequias mayores que facilitan el riego de su huerta, pero también proverbial su rotura, a veces con catastróficas inundaciones y, por ello, en 1482 para su reparo «fue toda la çibdad», menos los judíos, que prefirieron pagar 120 reales «en lugar de los peones que avia de dar». Lo mismo para arreglo de la acequia mayor de Alquibla, que también hubieron de abonar 120 reales. Al año siguiente, la aljama no quiso pagar "otros" 120 reales para las obras de las acequias mayores. Acuerdo de que se les hiciera padrón y les obligaran a ir dos días, miércoles y jueves, pero «non vayan mochachos". 


\section{CONTRIBUCIÓN A LA HERMANDAD}

Desde la implantación de la Hermandad se mantuvo un permanente forcejeo concejo-aljama por el propósito de incluir a los judíos en las derramas que por tercios se repartía anualmente entre la población pechera para la guerra de Granada. Hasta septiembre de 1489 no se produjo la decisión terminante del concejo por igualar a judíos y pecheros en su pago. La aljama se mantuvo firme en su negativa, oponiendo a sus pretensiones un privilegio real de 23 de febrero de 1486, por el que se les eximía de cualquier contribución municipal ${ }^{32}$, si bien, precavidos, la negativa nunca fue total, pues aceptando la realidad de una situación cada vez más grave por la continuación de la guerra y conocedores del malestar existente en la sufrida clase de los pecheros, convinieron el pago de 10.000 maravedíes anuales, que les resultaba más beneficioso que contribuir conforme se valoraran sus bienes.

Las perspectivas y condiciones en que vivían los murcianos en 1489 no podía ser más penosa; el cerco de Baza seguía exigiendo prestaciones económicas, humanas y materiales que agotaban posibilidades ${ }^{33}$, y una epidemia de pestilencia afectó gravemente a todo el reino ${ }^{34}$, con las consiguientes repercusiones, por lo que la penuria y necesidades crecieron desmesuradamente. Uno de los medios arbitrados fue intentar que los judíos participaran en paridad con los cristianos en la contribución de la Hermandad. Ante su acuerdo, el 19 de septiembre Abrahim Andanel, Mose Alfahar, Jato Abalanchi, Suleman Abenxuxe e Isaque Abenarroyo exponían públicamente que ellos pagaban «castellanos, cabeça de pecho e serviçios e medios serviçios e otras derramas universales de la aljama, salvo solamente en fuentes e en puente e en terminos» a que también estaban obligados. Insistían en que se respetaran las condiciones pactadas, pues "vues tra merçed nos rogo que por entonçe quisiesemos pagar aquellos diez mill maravedis, e que para adelante nos seria guardado el dicho previllejo, e por servir a vuestra merçed acordamos de lo azer en los años

32 «Demas del dicho serviçio e medio serviçio e cabeça nos han servido e sirven en este año e en los años pasados con çierta quantia de castellanos para el sueldo de la gente de armas que estan en nuestro serviçio en la dicha guerra de los moros." Por ello los Reyes dis. pusieron «non fagays sobre los dichos judíos repartimiento nin derrama alguna por la dicha guerra nin para peones nin bestias nin lievas nin por otra cosa alguna por via de Hermandad nin en otra manera", y si lo habían hecho lo devolvieran. García y García de CaStro, R., Las virtudes de una reina. Madrid 1961, reproducida por SUÁREZ, Documentos, pág. 95.

33 TORRES FONTES, "Las tribulaciones del concejo murciano en octubre y noviembre de 1489 " Anales Universidad. Murcia 1966, págs. 193-212.

34 TonRes Fontes, "Cuatro epidemias de peste en la Murcia del siglo XIV $(1412,1450,1468$, 1489)". Cuadernos de Historia, $n^{\circ} \mathrm{X}, 1983$, págs. 101-124. 
siguientes fasta oy por servir a muestra merçed avemos acordado de pagar los diez mill maravedis", pero no aceptaban y rechazaban la amenaza de ser empadronados.

El concejo decidió sobreseer, por entonces, la cuestión, si bien acordó enviar un emisario a Toledo para informarse de lo que allí se hacía, y al mismo tiempo exigirles el pago de los 10.000 maravedíes de una taja del año anterior y 5.000 del año 1489. La aljama, sin querer aceptar modificaciones, abonaba los 10.000 maravedíes el 2 de noviembre, recibiendo Mose Abençado en nombre de la aljama la correspondiente carta de pago.

El propósito concejil de obligar a los judíos al pago igualatorio de las derramas de la Hermandad se mantuvo y, por ello, dispuso el empadronamiento general de la población y de sus bienes. La cuantía de los pertenecientes a la judería se cifraron en 2.500 .000 y los de la morería en $50.000^{35}$. Presión y amenaza de efectuar la imposición que fue detenida por carta real de 29 de enero, en que se disponía que sólo contribuyeran con lo que por ellos estaba dispuesto. Lo que explica el acuerdo concejil de 5 de junio suspendiendo el cobro de las cantidades asignadas a judíos y moros de las derramas en que habían sido incluidos «por algunos respectos que a ellos les viene e porque los dichos sirven a su alteza en otros muchos serviçios e porque ayan algund alivio".

Debió mantenerse dura pugna en la Corte por los enfrentados apoyos que ambas partes encontraban, pues si en carta de 19 de julio los Reyes daban razón al concejo en su pretensión, atendiendo la pobreza y perjuicios que sufría la población pechera ${ }^{36}$, se contraponía con otra de 29 de julio en que se mantenía el privilegio que tenían los judíos, confirmada. el 27 de octubre, lo que suponía nuevo apoyo frente a las pretensiones concejiles.

La tensión se mantuvo en los meses siguientes, ya que el 27 de enero la exigencia municipal se renovaba y se hacía constar que hasta entonces nada habían pagado. Estos acuerdos y dilaciones, así como las contrapuestas cartas reales, quizá pudieran estar motivadas por la actitud de los regidores, a los que personalmente nada afectaba, ya que si en las reuniones adoptaban acuerdos, después no los hacían efectivos y se mostraban un tanto remisos a su cumplimiento. Pero el 5 de febrero, los

5 TORRES FonTES, «Población», en Estampas de la vida murciana en la época de los Reyes Católicos, 2." ed. Murcia 1984, págs. 225-236.

36 ABELLÁN PÉREZ, "Contribución económica de los judíos murcianos en la última fase de la guerra de Granada (1490-1492)", Estudios de Historia y Arqueología medieval. Cádiz 1981, págs. 55-60. 
jurados decidieron la cuestión al manifestar que no estaban dispuestos a cobrar a los pecheros en las derramas de la Hermandad en tanto no pagaran judíos y moros.

La solución fue hábil, ya que en 31 de marzo los regidores acordaban que las cantidades que se recaudaran de judíos y moros en la derrama para la guerra de Granada se emplearan en pagar los gastos que ocasionaban los pleitos de los términos en revisión, con lo que respetaban el privilegio real de exención, puesto que salvaba el pago de términos, puente y fuentes. La decisión definitiva la habían dado los Reyes el 15 de marzo al ordenar la forzosa contribución de judíos y mudéjares en las derramas de la Hermandad, salario del corregidor y pleitos de los términos ${ }^{37}$, además del reparto anual de castellanos.

La conquista de Granada y el fin de la guerra no beneficiaría a los judíos, pues la presión sobre la aljama sería cada vez mayor. Los 15.000 maravedíes entregados como albricias al mensajero de la buena nueva, los hubo de adelantar ante la falta de medios del concejo el genovés Tadeo de Negro, si bien exigiendo que algún judío se obligara a él por dicha cantidad, como lo hizo Mose Abenday; a ellos se sumaron los gastos de las fiestas conmemorativas de la victoria y fin de la guerra y se conminó a la judería a que en el plazo de tres días aportara como los demás vecinos el 10 por 1.000 de sus bienes, que en esta ocasión cifraron en los «çinco cuentos de cabdal que tyene», esto es, el doble que en 1489 y, por ello, le correspondía 50.000 maravedíes. El jurado Samuel Abolafia expresó su protesta y de nuevo alegó la exención que les proporcionaba el privilegio real. La situación había cambiado, por cuanto suponía la desaparición del enemigo granadino y ya no había freno que detuviera las decisiones de los regidores y ante la negativa de la aljama a pagar, el concejo dio orden a su alguacil mayor que llevara presos a la cárcel a los jurados de la aljama, a Cohen «el rico» y a don Mayr y los tenga «bien presos", hasta que abonaran el impuesto. Hubo de ceder la aljama, si bien negociando y de los 32.000 maravedíes que se le reclamaban de dos derramas anteriores destinadas a abonar sueldos de la gente enviada a la toma de Granada, pudieron llegar al acuerdo de pagar la mitad, con carta de pago el 10 de marzo de 1492. No parece que efectuaran otros abonos, puesto que el 31 de marzo estaba ya muy cercano.

37 SuÁREZ, Documentos, págs. 354-355. 


\section{DIEZMO ECLESIÁSTICO, VINO JUDIEGO Y 30 DINEROS}

La concesión del diezmo por Sancho IV permitiría a la Iglesia de Cartagena obtener unos ingresos económicos suficientes para su organización y mantenimiento, los cuales se fueron acrecentando al mismo ritmo que aumentaron los cultivos en los siglos siguientes; una eficaz organización y recaudación merced al apoyo real y a la utilización de armas canónicas, permitirían después una disputaba distribución obispo-cabildoiglesias. La recaudación, contabilidad, almacenamiento y venta pronto quedarían en manos de expertos judíos, que acabaron ocupando todos los puestos de la administración y almacenamiento de los productos que puntualmente eran ingresados en el granero mayor. La relación, aunque incompleta, de gran interés que nos ofrece Marsilla Pascual ${ }^{38}$, permite apreciar que entre 1469-1474 las rentas del carnaje, aceite, alhabas, sisa, miel y cera, pilas del Obispo (Alcantarilla y Alguazas) y del Obispado se hallaban en manos de judíos, algunos de los cuales alternaban su trabajo con otros propios del concejo.

Esta relación documental no sobrepasa 1474, pero cabe deducir que todo continuaría igual hasta 5 de septiembre de 1486, día en que el arcediano de Lorca comunicaba al concejo que el cabildo había ordenado que en adelante ningún judío arrendara los diezmos de la Iglesia, lo que no afectó a la decisión de los regidores que todo continuara igual.

Una ordenanza del Cabildo catedralicio muestra como en 1476 los judíos gozaban de una confianza, que para muchos entonces debió parecer excesiva y para otros, los de abajo, inconcebible osadía, la que tenían los fieles judíos que administraban el granero mayor en que se recogía el diezmo eclesiástico y la libertad como obraban. Ordenanza que parece más dictada por los perjuicios económicos que sufrían, que por lo que afectaba a la religión que profesaban y de la que eran destacadios ministros. Se denunciaba que los fieles judíos encargados de recibir en el granero eclesiástico los frutos de los diezmos: trigo, uva, cebada, etc., elaboraban el "vino judiego, que se llama caser», con todas las ceremonias judaicas que ellos acostumbraban hacer, ya que los dezmeros podían presenciar cómo tomaban el diezmo que llevaban desde sus casas y coMo «ellos mesmos pisan la uva e guardan el cubo en que las pisan que no lleguen los christianos a ella después de pisada por ellos; ni menos quieren que tangan los christianos el vino e si lo tañen derramanlo e ante

38 Marsilla Pascual, $F$. «Los judíos y el Cabildo catedralicio de Murcia en el siglo XV", M.M.M., n. ${ }^{\circ}$ XIV, 1990, págs. 44-84. 
lo quieren perder que no bever; e si lo han de medir con la cantara que los christianos han medido el vino, no lo mediran fasta tanto que ellos ayan lavado la tal cantara con muchas aguas e muchas vezes con çeremonias reprobadas en nuestra ley, así como si los christianos fuesen gentes o personas suzias o leprosas».

La denuncia se extendía a que todo esto lo hacían en domingo «e aquel dia lo saquan e fazen sus remostos e lagares en grand menospreçio del temor de Dios e del dia santo del domingo o de las fiestas que los christianos han de guardar"; aunque cabe pensar que quizá lo hicieran así para evitar la presencia de cristianos, para que no se sintieran agraviados.

Un segundo aspecto tiene esta ordenanza y era que muchos dezmeros no pagaban el diezmo y otros justificaban su negativa a llevarlo al granero eclesiástico por no ver cómo los judíos se aprovechaban para hacer su vino, pues consideraban «que mas justa cosa es que lo coman ellos e sus fijos pues lo trabajan, que no que lo coman e bevan los judios...».

Su consecuencia inmediata sería la prohibición de que tal vino judiego se hiciera en el granero mayor, con amenaza de multa a los fieles que no lo cumplieran de 20 florines para la obra de la iglesia mayor de Santa María.

También tenemos constancia que la Iglesia seguía cobrando los tradicionales treinta dineros a la judería de Murcia, su oficialazgo y con Cartagena, que dividían por mitad Obispo y Cabildo; lo mismo sucedía con los «30 dineros de la judería de Lorca», igualmente divididos por mitad, si bien la del Cabildo no iba a grosa como en Murcia, sino que se entregaban al mayordomo que tenía en esta ciudad, como testimonian los Fundamentos de la Iglesia de Cartagena del obispo Comontes, escrito a mediados del siglo $X V^{39}$.

\section{ARRENDADORES Y RECAUDADORES DE RENTAS REALES $Y$ CONCEJILES (1475-1492)}

La relación de los judíos que fueron arrendadores y recaudadores de las rentas reales y concejiles murcianas no sólo es cuantiosa, sino que

39 RoXAs y CONTRERAS, Diferentes instrumentos, bulas y otros documentos pertenecientes a la dignidad episcopal y Santa Iglesia de Cartagena. Madrid 1756. Significa la continuidad del tributo recordatorio de las 30 monedas de plata pagadas a Judas iscariote (San Mateo 26,17) y dineros cobrados en plata, suficientes para que el Cabildo abonara su sueldo al mayordomo que mantenía en Lorca. 
en algunas de ellas su ocupación fue total y permanente. Lo que con carácter genérico afirmó Sánchez Albornoz que «los judíos llegaron a monopolizar no sólo la recaudación y el arriendo de las rentas del fisco, sino las de cualesquier otros pechos o tributos, incluso el arriendo y recaudación de los impuestos y gabelas de los mismos concejos que habían protestado muchas veces contra la intervención de los judíos en el manejo de la Hacienda real de Castilla", refleja, a su vez, la secuencia murciana en los años que gobiernan en Castilla los Reyes Católicos, a su vez consecuencia de lo acontecido en el reinado de Enrique IV, ya que la documentación permite apreciar la mayor afluencia y presencia judía en la vida pública murciana. Aunque en este caso habría que suprimir las protestas del concejo, que no parece que fueran muchas, y sustituirlos por el bajo pueblo que sufría la extorsiones y excesos de recaudadores y prestamistas o presenciaban la libertad con que los judíos elaboraban su vino, lo mismo que la sujeción a la oligarquía que gobernaba su aljama, pero su voz no llegaba a las actas capitulares y sus represetantes, los jurados, si hablaron, lo fue a oídos sordos.

Difícil en unos casos, dudosos en otros, imposible en algunos, la relación personal de arrendadores y recaudadores resulta incompleta y confusa al encontrar la concesión de las mismas rentas y al mismo tiempo a distintas personas, que los documentos no acaban de aclarar, aunque en ocasiones estas coincidencias suponen la suspensión de unos por otros, como sucedió en mayo de 1478 entre David Aben Alfahar y Fernando de Alcalá; otras veces puede responder a distribuciones parciales. Mayor complicación las concejiles, pues el dividir y subdividir una misma renta fue frecuente, ya que reportaba al concejo ventajas en cuanto rapidez, mayor facilidad y mayores ingresos. Otras veces la formación de compañías, como en la contribución de la Hermandad en 1489, de la que fueron arrendadores Abrahim Aventuriel, Yuçaf Abeniazor, Suleiman Aben Lope, Ysaque Aventuriel, hijo de David, Mose Abenaex y Martín de Chinchilla.

La contribución de la Hermandad, pagada por el concejo anualmente por tercios, la obtenía mediante imposiciones muy diversas. Un acuerdo de noviembre de 1489, bajo el título de "Renta de las ynposiçiones e acreçentamiento», así lo aclara: «Dieron cargo los dichos señores a Lope Alonso de Lorca, regidor, e Alonso de Auñon, jurado, a a Johan de Cordova, jurado, para que desmienbren las rentas de la contribuçion ordinaria de la Hermandad como entendieren que cunple al bien publico desta çibdad e a la utilidad e provecho de la dicha renta".

Tampoco se acaban de aclarar algunas concesiones concejiles, ya que al superar algún postor en días sucesivos la puja de otro en razón del 
"prometido», e incluso tres y cuatro posturas, no siempre sabemos cuál finalmente el beneficiado, pues en ocasiones al no consolidarse las fianzas prometidas o los fiadores nombrados, el postor perdía la cantidad depositada y se adjudicaba al anterior, con lo que la duda se produce. Otra cosa es la cesión posterior de la mitad o parte de la recaudación y la mención de uno sólo de ellos, lo que supone que la atribución no sea del todo cierta. Una serie de rentas, de las que sólo tenemos breves y escuetas menciones, se relacionan por cuanto supone la recaudación de gabelas concejiles difíciles de precisar, pero sí los nombres a quienes había sido concedida.

Otros aspectos a considerar, pero en los que no podemos entrar, pues sería una investigación más prolongada, son los que pueden proporcionar nuevos nombres, como son la relación de fiadores, de «fieles", los que personalmente recaudaban, tal los del vino «judiego» de que he hecho mención; la continuidad de líneas familiares, que también aparecen en los puestos rectores de la aljama; la actividad comercial que muchos de ellos sumaban a la recaudación; la asociación con cristianos cuyos apellidos denotan ser conversos y un largo etc., que quizá quede para un tiempo más adelante.

1475. Alcabalas, tercias, almojarifazgo, servicio y montazgo, diezmo y medio de lo morisco. Luis Núñez de Toledo y Luis González de Ayllón.

14/5-1477. Diezmo y medio de lo morisco, diezmo y aduanas de Aragón, servicio y montazgo. Juan del Espinar y Francisco López de Segovia (E) servicio desde S. Juan de 1475 a S. Juan de 1478).

1475-1477. Alcabalas, tercias, almojarifazgo, cabeza de pecho de judíos y moros, diezmo de Aragón, servicio y medio servicio. David Aben Alfahar.

1477-1488. Alcabalas, tercias, almojarifazgo, servicio y montazgo. David Aben Alfahar. En 1479 traspasa la mitad a Ysaque Aventuriel. En 2-V1478 los Reyes suspenden a don David y en 7-V-1478 la conceden a Fernando de Alcalá. En 10-VII-1478 los Reyes la devuelven a David Aben Alfahar.

1483-1484. Alcabalas y tercias. Rabi Abraham del Sobrado y Samuel del Sobrado.

1485-1489. Alcabalas y tercias, Juan Díaz de San Ginés y Fernando de Villarreal. Con cesión en 1490 de la mitad a Raby Mayr.

1481-1483. Almojarifazgo, diezmo de Aragón, diezmo y medio de los moriscos, ganado. David Aben Alfahar. 
1484-1485. Almojarifazgo, diezmo de Aragón, servicio y montazgo, diezmo y medio morisco. Diego de Monasterio que traspasa a Fernando de Madrid, con poder a Mose Aben Alfahar en diezmo y medio de 10 morisco, y en Fernando de Villarreal servicio y montazgo.

1486-1488. Almojarifazgo, diezmo de Aragón, servicio y montazgo, diez y medio de lo morisco. Diego Monasterio, que traspasa a Fernando de Madrid.

1490. Almojarifazgo, diezmo de Aragón, servicio y montazgo, morisco, por mitad Mayr Melamed y Fernando de Villarreal.

1491-1492. Alcabalas, tercias, almojarifazgo, diezmos y aduanas, servicio y montazgo, morisco. Rabi Mayr Melamed, con nombre Fernán Núñez Coronel en 1492. Poder a Mose Abenaex y Juan Ramírez en 1490; a Salomon y Çag Seneor y Mose Abentaher en 1491, y a Mose Abenaex y Çuleiman Abenxuxen en 1492.

ALBAQUIAS

1480. David Aben Alfahar (las comprendidas desde 1457 a 1477).

1490. David Aben Alfahar [carta posterior de los Reyes Católicos (Córdoba 12-VII-90), ordenando no se pagaran].

DIEZMOS Y ADUANAS DE ARAGÓN

1475. Recaudador Juan del Espinar. Fieles Yahuda Bonjuga, Isaque Abeniçar.

1477. Fiel Mose Alfahar.

1481-1483. Arrendador y recaudador David Aben Alfahar.

1484-1487. Arrendador Fernando de Madrid.

1488. Fieles Yuçé Abenarroyo e Isaque Abravanel, Mose Aben Atafe en nombre Yuçé Abanaexe, Yahuda Abravanel en nombre de Isaque Abravanel.

1490. Fiel, Isaque Cohen.

1492-1494. Arrendatario Rabi Mayr con poderes a Salomon y Cag Seneor y Mose Abentabe. 
HERMANDAD

1478. Yuçaf Allori.

1479-1480. Isaque Abravalla. Traspasa un tercio a Isaque Aventuriel y Juan de Peñaranda.

1481-1483. Yuçef Axaques, Jacob Axaques, Abraham Almateri, Yuçé Abenlupe.

1484. Yuçaf Axaques.

1485. Isaque Abravalla.

1486. Fernando de Madrid con Çulema Abenxuxe e Isaque Abravalla.

1487. Salomon Aventuriel.

1488. Yuçataf Abeniaçar. Abraham Seneor poder a Luis de Villanueva.

1489. Yuçaf Abeniaçar, Mose Abenaex.

1489. Don Mayr y en su nombre Mose Aventuriel y Yuçé Alfatex.

1490. Yuçaf Abeniaçar, Yuçé Alfatex, Mose Aventuriel, Mose Alfahar.

HERMANDAD IMPOSICIONES

1480. Lana y pasteles: Çulema Abenaex, Gonzalo de Alcaraz.

1480. Grana: Çulema Abeniatar, Gonzalo de Alcaraz.

1480. Pescado cecial y paños: Isaque Abravalla.

1481-1482. Blanca sobre el pescado: Yuçaf Axaques, Abrahim Almateri, Jacob Axaques, Isaque Abravalla.

1481. Carne: Yuçaf Allori, David Focacha.

1482. Carne: Çulema Abenxuxe, Yuçaf Allori.

1484. Paños: Samuel Abolafia.

1486-1487. Carne: Isaque Abravalla, Salomon Aventuriel.

1488. Abrahim Aventuriel, Yuçaf Abenhaçan, Zulema Abenlupe, Isaque Aventuriel, Mose Abenaex.

1488. Imposición «nueva» del pescado fresco y salado: Isaque Aventuriel, Abrahim Aventuriel, Mose Abenday, Çulema Abenxuxe.

1489. Yuçaf Axaques. 
1490. Alfonso de Toledo ${ }^{40}$.

SISA

1474-1475. Juan de Peñaranda.

1475-1476. Yuçaf Allori (Yuçad Axaques).

1476-1477. Yuçataf Abenlupe.

1477-1478. Yuçaf Axaques (Yuçaf Allori).

1478-1479. Yuçaf Allori (Yuçaf Axaques).

1479-1481. Yuçaf Allori (Yuçaf Axaques).

1482. Yucaf Allori (Jacob Axaques).

1482-1483. David Focacha.

1483-1484. Yuçaf Allori.

1485-1486. David Focacha.

1486-1487. Yuçaf Allori.

1488. Yuçaf Allori (David Focacha).

1489-1490. David Focacha.

1490-1492. David Focacha ${ }^{41}$.

\section{ALCABALAS}

Heredamientos: Isaque Cohen, Rabi Abraham del Sobrado (1483-1484).

Pan, mitad: Fernando de Villanueva, 1489.

Carnaje: Rabi Santo, 1492.

Pan: Mose Alfahar, 1489.

40 Marín García, "El abastecimiento de carne en la ciudad de Murcia y su incidencia sobre el espacio agrario (1450-1500)", Murgetana, n. ${ }^{\circ}$ LXXV. Murcia 1988, pág. 80.

${ }_{41}$ Marín García, "Las carnicerías y el abastecimiento de carne en Murcia (1450-1500)", en M.M.M., n. ${ }^{\circ}$ XIV. Murcia 1988, pág. 77. 
RENTAS

Azud: Yuçaf Faluri, 1484.

Pan y vino: Abrahim Almateri, 1484.

Pan y vino: Isaque Abravalla y Álvaro Belcayre, 1485.

Seda: Isaque Zaradias, 1491.

Sal: Mayr Abendaño y Juan Talavera, 1486.

Huerta de Santomera: Isaque Aventuriel, 1488.

Corretaje: Yuçaf Alfandarin, 1490-1491.

ALMUDI

1488-1490. Yuçaf Abenaçan.

1490. David Focacha.

1492. David Focacha.

SERVICIOS Y GANADOS (mitad)

1489 y 1490. Isaque Cohen.

\section{CARNICERÍA}

Arrendatario durante muchos años de la carnicería Isaque Aventuriel, como también de rentas concejiles y reales, ganadero, trapero y otras actividades que ofrecieran beneficios por pequeños que fueran. Hombre con muchas peripecias en su haber y relaciones de distinto signo con el concejo, pues si hubo de sufrir penalizaciones por no respetar el número de cabezas en el ganado que mantenía en la huerta, o debía ofrecer en las carnicerías o por deficiencias de calidad o precio, en otras ocasiones se agradecian sus servicios, sus ádelantos económicos o préstamos. Una muestra de la equidad concejil se puso de manifiesto en 1478 al enfrentarse a un regidor y un jurado, quienes como Jueces ejecutores le tomaron injustificadamente unos paños y se negaban a devolvérselos. Conociendo la verdad y los derechos de Aventuriel, el concejo ordenó al regidor y al jurado su devolución $y$, de no hacerlo, les emplazaba a que el siguiente lunes «por la mañana se vengan presos a la sala desta çibdad e de alli 
no salgan sin su liçençia e mandado, so pena de çient castellanos para la obra del açud»».

Marín García nos ofrece una relación de los arrendatarios u obligados de la carnicería en esta época, en que bien se advierte la continuada presencia de Isaque Aventuriel y en algunos años en compañía de los Jaca, conversos de no muchos años antes y a cuya cabeza estaba Jerónimo, a quien el concejo gratificaba con 2.000 maravedíes por ser buen letrado y «sermoneador» a fines de 1474.

Obligadores:

1474-1480. Isaque Aventuriel.

1480-1482. Isaque Aventuriel y los Jaca.

1482-1483. Aventuriel, Jaca y Fernando de don Pedro.

1483-1484. Guillermo y Jaime Jaca.

1484-1485. Álvaro Belcaite.

1486-1487. Fernando de Madrid.

1487-1490. Aventuriel y los Jaca.

1490-1491. Isaque Aventuriel.

1495-1496. Juan de la Jara ${ }^{42}$.

Este intermedio 91-95, en que no hubo arrendatarios, sabemos por las actas concejiles que el 4 de agosto de 1492 los regidores solucionaron el problema de abastecimiento de carne concediendo libre venta y después con el reparto obligatorio entre los ganaderos de cabezas necesarias y proporcional a sus cabañas. Problema no ocasionado por culpa o quiebra de Isaque Aventuriel, sino su "calvario" por ser judío. El edicto de 31 de marzo supuso su ruina y encarcelamiento, pues obligado por tres años, su ganado le fue intervenido por el receptor de la Inquisición, quien oficialmente manifestaba que le había sido vendido. Hubo acuerdo con el concejo para la entrega de 2.000 carneros que estaban depositados en poder de los Jaca, para abastecer las carnicerías los días de Pascua, y convenido que el dinero que se obtuviera se entregaría al receptor a cuenta del débito de don Isaque.

El concejo se planteó la duda y hubo de consultar a sus letrados si podían apremiar a Aventuriel a cumplir su obligación y, en tanto, dispuso

42 Marín García, Las carnicerías..., pág. 78. 
que se pusiera «en mala boz los bienes del dicho don Ysaque e de sus fiadores porque esten a derecho». Lo que suponía aviso público de deudas pendientes. Esto sucedía el 24 de abril, lo cual también se extendió a David Focacha, arrendador de la sisa. El 16 de junio se dio orden de prisión de Isaque, su hermano Mayr, su hijo Yusuf y secuestro de sus bienes para seguridad de que cumpliría su obligación.

El 24 de julio se dispuso la continuidad en la prisión de Aventuriel hasta tanto que pagara lo que debía y el 31 de julio lo mismo contra su hijo, por ser fiador de su padre, aunque se hacía constar que no había otro cargo contra él. Las fechas apremiaban y el mismo 31 de julio el jurado Fernando Mateos se obligó por las deudas de Isaque Aventuriel a pagar hasta 100.000 maravedíes en plazo de treinta días. Fiadores suyos fueron el deán don Martín de Selva y Diego de Monzón, con lo que Aventuriel salió de su prisión. Acababa este día el plazo de los cuatro meses concedidos en el edicto de expulsión, aunque ampliado para compensar los días transcurridos hasta la llegada y recepción de la carta real por los concejos y consiguiente pregón. Cabe pensar que pudo trasladarse a Cartagena y embarcar, puesto que después de 31 de julio no sabemos más de él.

\section{RELACIÓN CIUDADANA}

La relación y trato que en la ciudad de Murcia mantuvieron concejo y vecinos cristianos con las minorías, que se integraban en la comunidad urbana, sólo la conocemos por todo cuanto se refleja en las actas concejiles y en un número no muy cuantioso de documentos reales y particulares, suficientes para poder apreciar la línea regular y rectilínea que el concejo mantuvo con ellas. La época de los Reyes Católicos no fue una etapa cronológica de mayor o menor extensión que otras, sino continuidad de una norma mantenida en el transcurso del tiempo, pues si en principio cabría deducir que hubiera podido ser factor decisivo el todopoderoso adelantado Pedro Fajardo, cuya autoridad indiscutida se extendió a todas cosas y en quien de alguna forma quizá pudo influir Mose Abendaçno, su mayordomo y hombre de confianza y a quien otorgó poderes excepcionales para la administración de sus bienes, después de su muerte todo siguió igual.

Si aparentemente 1480, año en que se celebran las Cortes de Toledo y 1481, en que con la visita de Juan de la Hoz se hacen efectivas o se anuncian las principales disposiciones acordadas en ellas, pudieran parecer hitos divisorios de dos etapas con referencia a la situación de los judíos, la realidad es que para la ciudad de Murcia no fue así. Hubo 
acuerdos, limitaciones y delimitaciones, pregones, prohibiciones, etc., pero sin trascendencia, porque las medidas que oficialmente se adoptan entonces no pasaron de ser algunas más de las muchas impuestas sobre ellas, pero sin efectividad. Se manifiesta así, en los variados acuerdos de los años siguientes y en relación directa de toda clase de persorias y en todos los aspectos que no quebrantaron el mantenido régimen de convivencia, que suponía bastante más que la simple y forzada coexistencia.

Todo igual hasta los primeros meses de 1492, pues no se alteraron las normas consuetudinarias, las costumbres establecidas en unas relaciones en las que nada quedaba oculto, en que todos se conocían y unos y otros sabían hasta donde y cuanto se podía llegar. La mayor tensión y fricción se produjo en 1490-1491, por el propósito y final consecución concejil de imponer a los judíos su contribución a las derramas de la Hermandad "por contyas de sus faziendas e non en otra manera", pese a que pagaban castellanos. $Y$ no fue por malquerencia religiosa o racional, sino porque las continuadas exigencias tributarias de la Hermandad, reales y concejiles, agotaban haciendas y medios a los pecheros y no pecheros, y con la inclusión de los judíos esperaban ver disminuidas sus aportaciones. No cuentan, porque lo contrario hubiera sido anormal, las quejas y agravios contra los recaudadores, pero cuando éstos sobrepasaban los límites convenidos o afectaban con exceso al mismo concejo, su penalización era contundente y la prisión o embargos inmediatos.

Facetas muy diversas de la vida cotidiana, fugaces escenas de las que sólo queda la huella del paso de algunos judíos que debieron alcanzar cierto renombre o gozar de la influencia necesaria para conseguir hacer efectivos sus propósitos, pero también lo contrario, los mal vistos cuya compañía o presencia resultaba indeseable y, a veces, odiosa; otros a los que se les encuentra mezclados en toda clase de negocios, donde la economía privaba, bordeando $u$ olvidando la legalidad y se aventuraban a comerciar con todo cuanto pudiera reportarles beneficios; algunos, cuya muy distinta, ofrecen los incompletos documentos y sin que podamos conocer todo el entramado en que se vieron envueltos; datos siempre escuetos pero suficientes para percibir unas formas de vida, de obrar y de relaciones públicas e incluso de desavenencias er, el interior de la judería. De aquí que recojamos estas notas dispersas de acuerdos concejiles y de documentos, cuya conjunción permite observar, sin entrar en valoraciones, aspectos muy diversos de la actividad de algunos judíos en estos dieciocho años.

El concejo elegía anualmente un alcalde para las cuestiones que se promovían entre cristianos y judíos, a la vez que el vicario resolvía los pleitos en que se encontrara afectado algún clérigo con ellos $y$, por su 
parte, la aljama resolvía los propios entre judíos, salvo cortas excepciones, pues en ocasiones alguna de las partes recurría al consejo o al rey cuando no lograba o no esperaba obtener la justicia apetecida. Es el caso de la judía doña Aldonza, que recurrió a la justicia no judía para denunciar a Mose Aventuriel por haber forzado a su hija Gracia, ya que la aljama, dominada por grupos familiares, entre los que se contaban los Aventuriel, siempre predominantes en la historia murciana desde el siglo XIII, no le ofrecía confianza alguna; otras veces pudo ser la fecha y lejanía, como la que motivó el que los Reyes atendieran en abril de 1492 la solicitud de Samuel Aben Hayon, vecino de Murcia, para que el pleito que tenían pendiente contra otros judíos, no fuera juzgado por Abraham Seneor, juez mayor de los judíos, sino por la justicia concejil.

Las andanzas y el carácter de un judío llamado Abeniacar es buen ejemplo de las decisiones concejiles de que la justicia fuera igual para todos. Lo fue cuando ordenaron la detención de Juan de Escortell, alcaide de cristianos y judíos, porque perdió la paciencia ante las provocaciones de Abeniacar, quien había acudido ante él para pedir justicia, y debió injuriarle de tal modo y de forma tan violenta como para que el concejo, considerando que "los juezes non an de ynjuriar a nadie que paresçe ante ellos a su juyzio e an de ser mas corteses e onestos que otros, e porque a el sea castigo e a otros exenplo», le ordenaron quedar preso en la sala concejil. El mismo Abeniacar, cinco años más tarde, provocó un altercado con el escribano Riquelme - con pleito precedente anterior-, y éste, más impulsivo, le dio una bofetada; tras el consiguiente juicio y declaración de testigos, de uno y otro lado, Riquelme fue desterrado de la ciudad y su huerta por tiempo de seis meses, con juramento entre los regidores de no revocar su decisión ${ }^{43}$.

Actitud concejil que se repite en otros muchos hechos, como cuando los regidores acordaron la devolución de ciertos paños a dos judíos por entender que lo ordenado por el corregidor «es injusto". Otro tipo, otras formas y posición fue Rabi Santo Aben Ros, subarrendador de rentas concejiles y con largo historial, mal visto por toda la población. Las noticias, que nos quedan, hacen referencia a un pleito que mantenía ante el juez mayor de las aljamas contra los judíos Mayr y Bensilay de la Cavallería, judíos moradores de Murcia y Lorca, relacionado con la muerte de su hermano, que solicitó y obtuvo seguro real temeroso de sufrir daños en su persona, casa o hacienda ${ }^{44}$. Al año siguiente era multado por el

${ }^{43}$ TORRES FONTES, «Las provocaciones de Abeniacar y la justicia concejil», en Estampas medievales, págs. 496-502.

${ }_{44}$ SuÁREZ, Documentos sobre la expulsión de los judios, doc. 43, en 27-1-80. 
concejo y protestaba de la sanción, por considerarla injusta. Diez años más tarde volvemos a encontrarle cobrando alcabalas y sisa, y era denunciado porque «fatiga e cobra» demás a los trajineros y el concejo le obligó a su devolución. El 18 de agosto de 1492, los regidores tuvieron conocimiento de que había salido de Almería con dirección a Murcia decidido a hacerse cristiano y recobrar su vecindad. La decisión concejo fue contundente: «si lo tal fuese seria grand dapno de la republica, porque el dicho Rabi Santo es onbre de muy malos tratos e conversacion". De aquí el acuerdo, de si se tornase cristiano le sería impedida su vuelta, ni avecindarse y prohibido fuese acogido por ninguna persona, con juramento de los alcaldes, regidores y jurados de no quebrantarlo ni volver sobre su decisión, ignorando la disposición real para los judíos que regresaran y fueran bautizados que le deberían ser devueltos sus bienes, y si habían sido vendidos por el precio que se hubiera pagado por ellos. «Trato e conversacion» inolvidables. Mejor lejos, cristiano o judío ${ }^{45}$.

No siempre el recaudador era "el enemigo», porque en ocasiones, aunque no muchas, el agradecimiento a su actuación resultaba expresivo. Tal el caso de David Aben Alfahar, recuadador por más de cincuenta años de las rentas reales en el obispado de Cartagena, que gozó del favor real con la concesión de privilegios excepcionales de Enrique IV y Reyes Católicos, con mal final, pues le fueron revocados en 1491. El concejo tuvo con el sus más y sus menos, como en 1481 en que adoptaron el acuerdo que se le diera tanto pescado como si fuera un regidor, porque «faze lo que el conçejo le ruega e porque es persona onrrada», lo que se contradecía después con decisiones contrarias, tanto como por carta expusiera sus quejas por el mal trato e invocara al "santo Job» "

Agradecimiento oficial también a Mose Abenaex, receptor de los maravedíes de la Hermandad en 1489 «por la buena obra que esta çibdad a resçebido del por la espera que ha fecho por los maravedíes». Esta dilatada detención en la recaudación fue un acto de comprensión al tener en cuenta las dificultades de los vecinos ocasionadas por la grave epidemia de pestilencia que afectó a todo el reino, así como la agobiante

45 TORRES FonTES, «El controvertido Rabí Santo», en Estampas, págs. 473-476.

46 TORRES FONTES, "Servicios y agravios del recaudador David Aben Alfahar», en Estampas, págs. 513-521. Figura singular, tan relacionado con la historia murciana, de cuyo reino fue recaudador de rentas reales por más de cincuenta años y que los documentos permiten siluetear con trazos firmes. Uno de sus hechos fue el obligarse voluntariamente con el concejo en que se pintara la imagen de los Reyes Católicos en la sala de la corte concejil «porque quede memoria del para adelante". Pasó el tiempo y al no realizarlo, el concejo le conminó a efectuarlo con advertencia que de no hacerlo, sería el concejo quien mandaría pintar a su costa. 
carga que suponía el sitio de Baza. Agradecimiento expresado en las actas concejiles y con la entrega, como obsequio navideño, de dos pares de gallinas y un par de capones. Como lo fue en 1484 con la concesión de un insólito seguro a Yuçé Axaques, un recaudador en quiebra y huido, para poder estar en la ciudad por ocho días sin ser preso ni detenido para rendir cuentas de las deudas que tenía, y con promesa del concejo, que si por algunas cosas pensara en proceder contra él, le apercibirían con tres días de antelación para que pudiera ausentarse libremente de la ciudad $^{47}$.

Cordial trato y atención para los profesionales judíos en Medicina, en muchos casos imprescindibles. Gratificación de 500 maravedíes al cirujano Yuçe para ayuda de los gastos de su matrimonio. Si en 1478 se repetía la prohibición a los judíos del ejercicio de físico o cirujano sin haber sido examinados bajo pena de 100 maravedíes, «aunque pudieran usar de ojos», en 1484 otorgaban título de cirujano a Yuçaf Axaques, y recordando a su padre, por muchos años cirujano de la ciudad, le concecían exención de tributos concejiles agradecidos a sus servicios. Así, sucesivamente, porque también en 1848 dieron su apoyo y seguridad a Cadenera para su oficio de cirujano fuera común a todos, cristianos, moros y judíos, «e sy despues de curados non le pagaren, lo pida por justiçia e ge la administraran»; lo fue la concesión de una torre en la muralla al cirujano Abraham junto a sus casas. Y la negativa, pues en 1484 se notificaba a los boticarios judíos no usaran del oficio «fasta tanto que se de con ellos la orden que se a de dar»; prohibición real y concejil que se reiteraba de trabajar como boticarios, y tres años más tarde se encargaba al doctor Loazes y Aben Rabi que «vean e exsaminen los botycarios desta çibdad e las melezinas que tienen e sy fallaren que son malas se las derramen».

Un tema siempre candente: la usura. Difícil conocer, pero, con lo poco que contamos, podemos apreciar la actitud concejil de mantener la línea de la legalidad. En 1475 lograron salvar a un judío de las garras de una viuda usurera mediante ardua pesquisa que permitiría anular dos contratos tan excesivos como para reducir la deuda con los intereses que había pagado ${ }^{48}$. En el mismo año, un judío platero encontró apoyo concejil frente a un cristiano logrero al que había denunciado por préstamos usurarios y que le fatigaba con continuos pleitos, a lo cual puso coto el concejo con el anuncio de encarcelarlo si continuaba en su persecución. Caso contrario, el de los regidores apremiando a los alcaldes de la Her-

47 ToRres FonTES, «Los engaños familiares», en Estampas, págs. 457-460.

48 Torres Fontes, «Los deudas de Mayr Bonafox», en Estampas, págs. 461-470. 
mandad a ejecutar una sentencia dictada contra Rabi León por usura y que no ejecutaban por temor que en la apelación fuera revocada y ellos condenados en costas; sólo cuando el concejo les aseguró de sacarles en salvo, se mostraron dispuestos a llevarla a efecto. Sus razones tendrían, porque en 1486 Isaque Aventuriel y Abraham Aventuriel, en nombre de la aljama, presentaban carta real disponiendo que no demandaran a los judíos las penas de los logros, y el concejo decidió acatarla, si bien disponiendo su inserción en el cartulario correspondiente para salvaguardar su obligada detención.

No faltaron malos usos como fue un gravamen que encontramos a todo lo largo del siglo $\mathrm{xV}$, aunque afortunadamente discontinuo, como era la exigencia, no ilegal por tiempo, sino costumbre convertida en ordenanza concejil de atender a los corregidores cuando tomaban posesión de proporcionarle vivienda y ropa de cama, que el concejo traspasaba parcialmente en lo referente a "cama» a judíos y moros, en proporción a los respectivos vecindarios. Así en 1479: cama con dos colchones de lana, dos pares de sábanas, manta, colcha y dos almohadas para el corregidor, y para uno de sus hombres cama de dos colchones de borra, par de sábanas y manta, correspondió a la judería, en tanto que a los mudéjares se les exigió una cama para un sirviente. En 1480 se pidieron camas para el oficial del corregidor que sirviera por cuatro meses, y para el alguacil y escribano dieron orden a los jurados de la judería que repartieran, entre ellos, dos cobertores, cuatro sábanas de lino, dos colchones, dos mantas, colcha y almohada. Excesos que en 1483 se valoran en metálico, fijándose en 5.000 maravedíes, a repartir 2.000 judería y 1.000 morería, y el resto el concejo; un mes más tarde la proporción aumenta y se establece, cuatro, tres y uno. En 1484, si para la entrega de lo estipulado con el corregidor hubo conformidad, su petición para el escribano fue rechazada por los jurados, que se opusieron diciendo que no se les podía exigir más. Excesos que acaban cuando los jurados invocaron la ley de Toledo y los regidores revocaron sus acuerdos y no volvieron a ordenar tales entregas.

Eran las personas, y bastante más sus obras, las que creaban ocasionalmente imágenes adversas y sus abusos, denunciados cuando cesado en su oficio y alejado del reino, resultaba difícil penalizarlos. Todo porque el corregidor no supo impedirlo a tiempo. Denuncia de judíos y cristianos contra el alguacil Noreña, que ofrece una doble consecuencia, como es deducir que tales hechos se repetirían con cierta frecuencia, lo que no es cierto, pues es caso único en estos dieciocho años, y porque al recogerla en las actas concejiles los regidores mostraban su oposición a estos abusos. Tres fueron las denuncias de los judíos, aparte de otras de cristianos, por sus cohechos, arbitrariedades y abusos. Las malas he- 
churas de Noreña quedaron expuestas cuando se apoderó de colchas y otras prendas que estaban sujetas a pleito entre cinco hermanos, y las entregó a una de las hermanas, con la cual "dolmia»; todo por valor de 5.000 maravedíes, que el depositario reclamaba; otra fue que habiendo autorizado a jugar en casa particular, entró en ella y olvidando su licencia, se llevó una olla de cobre y otros objetos valorados en 2.000 maravedíes; y la tercera llevarse una saya de grana femenina, valorada en 1.500 maravedíes. $Y$ el concejo puso remedio a estas denuncias.

Otras veces los culpables eran los propios judíos. No la conocemos, pero debió ser grave penalización pecuniaria la que se impuso a Salomon Aventuriel y a Mose Aben Alfahar, lo que no impediría actividades posteriores de carácter oficial. Hubo denuncia en la Corte que por la frontera de Lorca se traficaba con armas, cereales, carne, queso, aceite, paños, fustanes y otros artículos, en su mayor parte prohibidos, pero en 1484, en plena guerra de Granada significaba aprovisionar al enemigo y facilitar su defensa. Tan conocida esta actividad como para que si en 12 de mayo los Reyes designaban al pesquisidor Nuño Orejón para intervenir y juzgar, en 15 de mayo ambos «sacadores" eran detenidos. No mucho después Mose Alfahar comerciaba y arrendaba rentas reales ${ }^{49}$.

Otro era el caso de Salomon Aventuriel, a quien indistintamente se le menciona como morador en Lorca y Murcia y que comerciaba con todo, incluso esclavas blancas. Unas de éstas las traspasó a su hermano Isaque, quien a su vez las vendió a Diego de Toledo, al cual se las tomó Juan de Benavides, capitán mayor de la frontera, quien alternaba las armas con los negocios, por débitos de Salomon. Éste había muerto en 1489, y Benavides reclamó contra su hermano Isaque por las deudas pendientes, quien se negó a cualquier acuerdo. Al año siguiente era Yuçé Aventuriel, hijo de Isaque, quien reclamaba contra los bienes de Salomon. La cuestión sobrepasó a 1492, pues un año después el Consejo real ordenaba que se hiciera justicia a Diego de Toledo, quien seguía sin recobrar las esclavas y su dinero.

A Benavides lo encontramos en diciembre de 1491 en negocios con el judío Samuel Abofalia, quien no había proporcionado toda la seda joyante, toca tunecí y un «fostal» de oro y seda amarillo a que estaba comprometido y establecía nuevo plazo con el procurador de Benavides para hacerlo efectivo, lo que por la fecha no parece que así se hiciera.

Próspera fortuna de Grabriel Israel, morador en Lorca, pues si en junio de 1476 fue obligado a devolver unas viñas indebidamente tomadas, ca- 
torce días más tarde recibía el título real de trujaman ${ }^{50}$, lo que aparte de la amplitud de sus funciones como escribano e intérprete de lengua arábiga, se añadía la de alfaqueque. Y como tal conocemos su intervención en el rescate de Fernando Dombre, cautivado en la expedición de Abul Hasán de 1477, cuando asaltó Cieza y se llevó cautiva la mitad de los que allí se encontraban, pues los demás fueron muertos. Para su gestión obtuvo poderes previos de la mujer y sobrina del cautivo para cobrar de sus bienes cuanto gastara para lograr su libertad, lo que motivaría su gestión en Jumilla para hacerlos efectivos.

Cuando surgió un nuevo negocio, incipiente a mediados del siglo, pero su incremento fue tan rápido que ya en la década de los ochenta adquirió importancia tan grande que en él se mezclaron cristianos, judíos y genoveses, e incluso motivaría la conversión de dos judíos y sus familias. La seda, negocio floreciente en donde el trabajo y minuciosidad judía encontró próspero medio de vida. Con su crecimiento surgieron los primeros problemas y su comercio con Toledo obligó a la intervención concejil para controlar y vigilar su producción, dada la repercusión económica que había alcanzado. Una de las medidas adoptadas fue en abril de 1478 cuando mediante pregón se prohibió que los judíos pudieran hilar seda en la judería, con pena de 600 maravedíes y la misma pena a los cristianos que la llevaran. Un incidente en 1485 facilita una doble perspectiva, los filadores de seda «porque aquellos son judios y aun los mas dellos tranposos», denunciándose su mal obrar porque «obran mala seda», lo que motivó extremar la vigilancia y su consecuencia fue el enfrentamiento de Juan Aniorte, veedor de la seda, con el hilador Cohen, que terminó con dos bofetadas del cristiano al judío, seguida de la inmediata prisión de Aniorte, multa y diversos pagos para su salida de la cárcel ${ }^{51}$. Negocio de la seda ascendente y, por ello, la llegada de hiladores extranjeros, por lo que el concejo dispuso en mayo de 1491 examen obligatorio para poder trabajar. A ellos se unieron dos judíos conversos, bautizados en Ibiza «alunbrados por el Espiritu Santc», y Antonio de Grimaldo y Carlos de Peralta desembarcaron en Cartagena, recobraron su perdida vecindad murciana y después pidieron exención en el pago de almojarifazgo de las cosas que traían pertenecientes al "arte nuevo de la seda e de otras cosas e maestros", con lo que entendían servir a la ciudad, con lo que sería

50 Según Baer la concesión del título de trujaman a Gabriel Israel fue por los servicios prestados en la guerra de Granada, lo que está en contradicción con la fecha de concesión, en Madrigal, 18-IV, 1476 (TORRES FONTES, Don Pedro Fajardo, adelantado mayor del reino de Murcia. Madrid 1953, págs. 278-279 en donde se publica).

51 TORRES FONTES, «La inquina de Cohen el sedero", en Estampas, págs. 502-506. 
«honrrada e aporvechada». No hubo impedimento para su vuelta, exención y la puesta en marcha de su negocio ${ }^{52}$.

En el trato, la alternancia de medidas prohibitivas o una tolerancia que no tenía más límites que aquellos establecidos y respetados, tanto en religión, relación con cristianas y alimentos. Es así en estos años cuando el concejo se dirigió a la aljama para que pusieran penas a cualquier judío que vendiera vino, queso o carne, a cristiano sin manifestarlo primero, con pérdida de la mercancía, 600 maravedíes de multa a los contraventores, lo que no significa el que no se vendiera, como cuando en 1480 el concejo tasó a 8 maravedíes la libra del queso judío para su venta a cristianos. Prohibición también que la candela para confirmaciones y bautizos de cristianos fuera facilitada por judíos, con amenaza de pena de muerte para los vendedores y expulsión de la ciudad a los compradores por malos cristianos.

Sólo dos conversiones, aparte de los sederos Grimaldo y Peralta, conocemos. La de Jerónimo de Jaca, a quien por su conversión, por ser buen letrado y «sermoneador» se le concedieron 2.000 maravedíes de ayuda de costa. O la de Gonzalo Carranza, que converso con anterioridad a 1492, casado con cristiana, solicitaba recuperar las casas en que había vivido en la judería. En cambio resulta extraño el nombramiento del inquisidor Francisco González Francos para que redacte informe sobre los judíos que islamizaban en el obispado de Cartagena en fecha tan tardía como 1490.

Más atenuadas serían las ordenaciones jurídicas y de contacto. Una fue que los judíos no pudieran ser procuradores por cristianos ni al contrario, salvo en las rentas reales. Otras más costumbristas, pues si los judíos fueron denunciados porque «encarecen las gallinas en el mercado», y los regidores le prohibieron comprar pollos y gallinas los jueves, día del mercado, solo a última hora, hasta que fuese tocada la campana de la "oraçion del Cuerpo de Dios", excepto en el mes de diciembre, tal ordenación discriminatoria quedó en suspenso tres años más tarde. O la que no tardó en quedar incumplida, como otra ordenación pregonada que nadie dejase sus caballos y mulas de silla a judíos y moros para sus bodas. Todo dependía del corregidor de turno y del tiempo en que se haciáa ${ }^{53}$.

52 TORFES FONTES, «La industria sedera y los judíos», en Estampas de la vida murciana en la época de los Reyes Católicos, 2. ${ }^{a}$ ed. Murcia 1984, págs. 11-19.

53 En 1477 el concejo dio licencia al pintor Destosa, judío para ejercer su oficio, pero «que no pueda pintar ymageneria». 
En diciembre de 1488 se produjo un hecho que muestra mejor que otros muchos la actitud del concejo con sus vecinos de la judería. Leví de Najara, judío tundidor, fue examinado por tundidores cristianos con resultado negativo, pues le consideraron no apto para tal oficio. Leví se quejó ante el concejo y denunció que quienes le negaron capacidad para su trabajo lo hicieron por enemigo que le tenían «por ser de su ofiçio e por ser judio», solicitando le hicieran justicia. Denuncia por discriminación, que motivó la inmediata reacción concejil, y fueron designados el corregidor, dos regidores y un jurado «para que tomasen de salto a los dichos tundidores y en el primer paño que alli se tondiese fiziesen tondir al dicho judio, e alli se vería si se fazia con malizia o con verdad». La comisión, acompañada por el judío, se presentaron sin previo aviso en la calle Trapería e hicieron tundir a Leví un paño pardillo que allí se estaba preparando. Los comisionados tomaron juramento a dos tundidores, el cristiando Diego Reyes y el judío Yanto Cohen, para que expusieran su parecer respecto al trabajo efectuado por Leví de Najara y, ambos conformes, juraron que «yva tan bueno como los que ellos tondian».

El corregidor tomó después juramento al tundidor Juan de Nabares, a quien también pidieron expusiera su criterio y «dixo que yva comunal y que no yva igual», así como que su examen no debía hacerse sobre tales paños, que dentro de dos o tres días daría paño que demostrara sus conocimientos. No debieron ser tan convincentes estas afirmaciones, porque si bien decidieron que se hicieran nuevas pruebas tiempo adelante, en tanto habilitaron a Leví para que «tunda en conpañia de los tundidores christianos del dicho ofiçio». Los regidores no aceptaban discriminación, otra cosa era su competencia.

Una labor delicada y valiosa, que exigía especialización y habilidad, era la de frenero, por lo general escasos y bien cotizados. En estos años permanecieron en Murcia los judíos freneros David Najarco, con gratificación anual de 500 maravedíes para alquiler de su taller; Salomon Çalema, con igual gratificación, y su hijo Isaque, a quien en 1491 se le contrataba con tal cantidad pero en concepto de salario. En la misma fecha se atendía una petición, cuya concesión mostraba la atención concejil a lo que pudiéramos considerar capricho judío, pues les autorizaron a tener dos cazadores de perdices, que debían ser nombrados ante escribano, si bien sólo para tenerlas vivas en sus casas. Ya en 1491 podemos apreciar cómo los judíos habían formado compañías con mercaderes genoveses en el comercio internacional para la exportación de alumbre de Mazarrón. La formaron la familia Rey y Samuel Cohen, si bien el último contrato de compra, de 871 quintales de alumbre al precio de 350 maravedíes el quintal, no debió de cumplirse enteramente, por cuanto se especificaba el pago de 200 quintales en el mes de septiembre de 1492 
y los 671 restantes en el mes de octubre. No conocemos su resultado ni que fue de Samuel Cohen, pero sí estamos ciertos que judíos y genoveses comerciantes, se conocían y se entendían.

\section{POBLACIÓN Y BIENES}

La posibilidad de cifrar la población que se apretujaba en el recinto urbano de la judería murciana no es grande, no sólo faltan padrones, sino que la estancia transitoria de muchos de ellos por la facilidad que tenían para trasladarse al vecino territorio aragonés y las distintas fases de conversión, que implicaban disminución, no contrarrestados por la llegada de nuevos vecinos. Todo ello impide obtener datos concretos y mucho menos relación nominal, aunque fuera parcial, como en los comienzos del siglo $X V^{54}$, que pudieran permitir algo más que una deducción.

A lo largo del siglo $x v$ es perceptible en Murcia la afluencia de nuevos vecinos procedentes, en su mayor parte, de la Corona de Aragón, con detención casi total en la época de los Reyes Católicos; la ciudad crece y la mejora del nivel de vida es perceptible a igual que su economía; aumenta la ganadería y la actividad mercantil encuentra nuevos derroteros y medios, en que la seda y el alumbre pronto salen al exterior; renovación de cultivos con desarrollo espectacular de la morera, base de la producción sedera; creación de pequeños señoríos huertanos sin jurisdicción, roturación del campo, abandonado durante siglos y gradual repoblación, aunque la demanda de tierras es continua, al mismo tiempo que se desecan tierras en la zona de Monteagudo. Todas ellas y otras menores son manifestaciones de un profundo cambio que repercute en la vida cotidiana de la capital y en la que el trato y contacto con los judíos es permanente.

La década que se extiende desde 1482 a 1492, pacificada Castilla, la política real, y tras ella la de todos sus súbditos, se centra en la guerra de Granada, a la que se subordinan toda clase de actividades humanas y económicas, y aunque no participen directa ni personalmente en ella, los judíos se verían afectados por sus exigencias tributarias cada vez mayores para atender el considerable gasto que suponía la contienda. Es precisamente la cuantificación de bienes y los impuestos que recaen sobre ellos, al repartir las cantidades que se asignaban a cada reino, ciudades, morerías y juderías, aunque no quede padrón completo, las que sus re-

54 TORRES FONTES, «LOS judíos murcianos a fines del siglo XIV y comienzos del Xv», en M.M.M., n. VIll. Murcia 1981, págs. 55-117. 
sultados finales permiten aproximarnos al conocimiento del número de vecinos o casas, ya que de una u otra forma se expresan en una misma acta concejil, en la imposición de las derramas establecidas.

No son aceptables ni útiles los datos referentes a la población castellana con la imposición para la Hermandad de 18.000 maravedíes por cada cien vecinos. La primera cuantificación de la grey judía, que parece responder fielmente a la realidad, es cuando en enero de 1481, siendo insuficiente la asignación que anualmente concedía el monarca para arreglo de las murallas de la capital, obligó al concejo a hacer un reparto de 30 maravedíes por vecino ${ }^{55}$. A la judería se le asignaron 5.000 maravedíes, lo que correspondía a 166 vecinos. La impugnación judía surtió efecto y los regidores aceptaron la protesta de la aljama, agraviada «porque no avia tantos vecinos"; lo que reconocido por el concejo, lo redujo a 4.500 maravedíes, lo que suponía asignarles un total de 150 vecinos, que, como se mostraría posteriormente, resulta aceptable.

En 1484, nueva imposición para abonar el gasto que obligadamente tenía que realizar para el envío de peones en el socorro y abastecimiento de Alhama. Esta vez la distribución del gasto se hizo atendiendo a la condición económica personal y se establecieron tres tipos: mayores haciendas, a 62 maravedíes; medianos a 42 y menores a 22. El resultado fue: mayores 435 , de ellos 42 judíos (9,65 por 100); 516 medianos, entre los que se encontraban 36 judíos $(6,97$ por 100) y 878 menores, de los cuales 63 eran judíos $(7,17$ por 100). Supuso, por tanto, la proporción 1.828 pecheros, de los que 141 (7,70 por 100) eran judíos. La aplicación del coeficiente 5 proporciona un total de 705 personas, a las que habría que añadir los que no fueron incluidos en la relación por carecer de bienes, ya que es indicativo que el sólo afectó a "los vezinos que se fallara que podian pagar lo susodicho».

Tercera fuente es el empadronamiento general que el concejo mandó realizar en el año 1488 para conoser número de vecinos y haciendas y efectuar una derrama de 4 maravedíes por millar para la Hermandad. Judíos y moros se conjuntan en un total de 204 vecinos, y dado que las haciendas sí se diferencian en 2.500 .000 y 500.000 , esta misma proporción cabe aplicarla a las cifras de población: 164 y 20, más aún por cuanto conocemos que la morería a mediados del siglo xv contaba 16 vecinos, y en otra ocasión 17; sólo en 1495, con la llegada de mudéjares granadinos, se había elevado a 43.

55 Molina Molina, «Datos sobre sociodemografía murciana a fines de la Edad Media (14751515)», Anales Universidad, 1979, págs. 169-183 
Si recurrimos a otra fuente, al número de judíos que pagaban castellanos, y dejando aparte lo consignado en el año 1485, a todas luces excesiva, en cambio los dos restantes años que conocemos, la proporción se mantiene con pequeñas variantes propias de las circunstancias y de lo que era una imposición real y otras concejiles; al mismo tiempo, teniendo también en cuenta que dos tercios era por cabezas y un tercio por capacidad económica. En 1488 fueron 171 los judíos afectados (51114) y en 1490 lo serían 143 (47-96).

Resumiento lo expuesto tenemos 150 vecinos o casas en $1481 ; 141$ en $1484 ; 164$ ó 171 en 1488 y 143 en 1490 . Parece que el coeficiente 5 es el más aceptable, lo que proporciona una población total de la judería en esta década de 700 a 900 personas.

Estas aportaciones económicas que la ciudad de Murcia y su reino hubieron de satisfacer para la guerra de Granada, que obligaron repetidas veces a empadronar a sus vecinos por parroquias, con inclusión aparte de judíos, moros y cuantos habitaban en los pequeños poblados y señoríos que se fueron creando en la huerta, son los que proporcionan relaciones de haciendas; padrones que se repitieron con cierta frecuencia, tanto por las continuadas exigencias humanas, económicas y materiales, como por las protestas de quienes se consideraban agraviados, aunque son pocas las veces que se incluye a los judíos. No son muchos los datos, pero como en las cifras de población resulta necesario aventurarse para aproximarnos a conocer lo que poseían en estos años.

Valoración siempre cuestionable porque no a todos debió afectar, ya que algunos sin casa propia eludirían el pago de estas derramas concejiles y al no contar con bienes inmuebles dejarían de incluirse en las relaciones y repartos que confeccionaban y recaudaban los jurados de la aljama; tampoco es posible contabilizar a los que se marchaban en períodos de crisis o los que sin medios económicos no participarían en los repartos.

Aunque no se especifica la forma empleada para contabilizar bienes, cabe pensar que debieron contar las casas; se tendría también en cuenta la cuantía en que estaba cifrada la vecindad; no faltaban propietarios de numerosas cabezas de ganado lanar, a veces propias, a veces asociados a clérigos y caballeros; otros cualificados por su intervención en la recaudación de toda clase de impuestos; préstamos; comercio menor, talleres dentro y fuera de la judería; pocos los que poseían tierras en la huerta, ya que en 1480 , cuando se efectúa una derrama para reparo de la Contraparada, se acordó un reparto de 4 maravedís por millar, y en la judería sólo se contabilizaron la propiedad de 659 tahúllas en el total de las 52.579 que entonces comprendía la huerta, aunque posiblemente 
acensadas; sabemos que en 1481 Pedro Gallego fue autorizado por el concejo para tener de noche un par de mulas en la heredad de Cohen, si bien atadas a una estaca. Años antes el recaudador David Aben Alfahar renunció a 10 tahúllas que tenía junto a la acequia mayor de Alquibla, porque el concejo le exigía pagar tajas para arreglo de la Contraparada. En cambio, Mayr Bonafoz recibía en 1483 cahiz y medio de tierra de secano en el puerto del Garrofillo en concepto de aparcería, por lo que pagaría a su propietario Simón de Monclus celemín por cahiz recolectado.

Exentos en el pago de Hermandad, peones y otros impuestos, los judíos no comienzan a ser incluidos en estas relaciones hasta 1488 , en que se intenta incluirlos en los repartos de la Hermandad, es, por ello, cuando en 1488 se cifraron sus bienes en 2.500 .000 maravedíes; otra derrama en 1489, con imposición de 7 por millar proporciona valoración semejante; lo que se dispara hacia arriba en 1492, tras la ocupación de la capital granadina, en que para atender los variados dispendios hechos y por hacer se llegó a una cuantificación arbitraria al evaluar sus haciendas o bienes en 5.000.000 de maravedíes, el doble que tres años antes. Revisión que pudo realizarse por la aportación de nuevos datos o a tenor de las circunstancias y tiempo en que se efectúa. Si en 1488 el total de bienes alcanzaba a 40.160 .000 , descontados los 2.500 .000 de la judería, sus haciendas suponían el 6,22 por 100 , y en 1489, el total de aportaciones para diversas partidas fue de 328.260 , descontados los 10.000 maravedíes de la judería, que representaba el 4,87 por $100^{56}$.

\section{EXPULSIÓN}

Por cuanto tuvo de inesperada la orden de expulsión para la mayor parte de las aljamas y por el corto plazo que iban a disponer los judíos para dejar su fe o salir, los problemas fueron generales, graves y angustiosos para toda la grey judía y las soluciones nunca satisfactorias. En lo que afecta al reducido horizonte murciano no se advierte hasta el mes de marzo cambio o asomo de cuanto se estaba preparando, y los arrendamientos concejiles a judíos, las formas de vida y relación ciudadana, siguieron siendo las mismas. Dos aspectos procede a considerar: el de las disposiciones reales de carácter general que llegaron a Murcia después de la carta notificando la expulsión, aclaratorias y complementarias, con referencia a la salida de las juderías y marcha hacia los puertos, así como

\footnotetext{
56 TORRES FONTES, «Población», en Estampas de la vida murciana en la época de los Reyes Católicos, 2. ${ }^{a}$ ed. Murcia 1984, págs. 227-235.
} 
la forma de disponer de sus bienes, y por otra las decisiones concejiles para llevarias a efecto en la línea comprensiva que siempre había mantenido con sus vecinos y las consecuencias personales que conocemos de algunos judios y conversos.

Tres cartas reales de 14 de mayo amplían la vía impuesta para el mejor cumplimiento de cuanto se había ordenado. Una, confirmando la libre disposición de los judíos para la venta de sus bienes muebles y raíces, semovientes y deudas, así como para dar, trocar o cambiar dentro del plazo fijado en el edicto, de la misma forma que lo hubieran podido hacer antes de 31 de marzo y ofreciendo plena seguridad a quienes adquirieran o cambiaran bienes judíos de no sufrir impedimento alguno de todo cuanto hubieran concertado ${ }^{57}$.

En el mismo día, y atendiendo la solicitud de los representantes de las aljamas, ordenaban que se les facilitaran bestias, carretas, bueyes y cuanto fuera necesario para llevar sus bienes y personas, a precios razonables que debían ser tasados por las justicias de cada lugar; se fijaban trayectos con un máximo de 20 leguas para los dueños o quienes llevaran las bestias y carretas si no querían seguir adelante y, en este caso, las justicias debían proporcionarles otros tantos medios de transporte y en iguales condiciones.

La tercera orden real estaba dirigida al almirante mayor, capitanes, patrones, maestres y contramaestres, pilotos y marineros de cualquier nao, galera, carraca o fusta, de armada o de mercadería. Carta motivada por el recelo que tenían los judíos si al embarcar podrían ser presos o cautivados y tomados sus bienes, pues temían que algunos intentaran aprovecharse de una antigua ordenanza real que prohibía a los judíos navegar bajo pena de quedar reducidos a esclavitud y recibir otros daños y agravios. La buena disposición real aseguraba personas y bienes de cuantos quisieran embarcarse, si bien manteniendo la reiterada prohibición de sacar oro, plata, monedas y otras mercaderias no permitidas.

Otro problema de carácter general era atendido por los Reyes en 16 de mayo, en respuesta a la solicitud judía para mejor resolución de cuanto no se había especificado o de necesaria ampliación de cartas anteriores, puesto que era más complejo, ya que se trataba de las casas y heredades adquiridas, pero no pagadas en su totalidad; otras acensadas y contratos de compraventa no acabados; mercaderías y bienes muebles que no «an

57 Amador de los Ríos, J., Historia social, política y religiosa de los judios de España y Portugal., págs. 1006-1007. 
pagado el preçio porque se convinieron". Las aljamas exponían que si para saneamiento de tales contratos se les obligaba a vender o hipotecar otros bienes raíces o buscar fiadores, les acarrearría perjuicios, pues tendrían que vender a menores precios de su valor real. La petición fue atendida: cuanto no estuviera totalmente pagado debía revertir a sus dueños con deducción de lo cobrado, aunque percibiendo alquileres no abonados y los daños que se hubieran producido y al contrario, satisfaciendo las mejoras efectuadas; al mismo tiempo, se daban por nulas las compras o contratos de censos y obligaciones, y se otorgaba licencia para vender los bienes, por los que se hubieran obligado o hipotecado, con devolución de lo entregado como comienzo de pago.

También en 16 de mayo, los Reyes señalaban vías resolutivas para las deudas. Los judíos debían y se les debía. Ellos no podían pagar nada más que con otras deudas o bienes raíces. Fórmula equilibrada fue la de conceder plazo de veinte días, previo pregón, para que se presentaran las deudas pendientes ante las respectivas justicias, las cuales con dos hombres buenos las estudiarían y resolverían. Pasado el plazo, los judíos podrían designar procuradores cristianos o moros a quienes traspasar las que tuvieran pendientes para que se cobraran en los plazos señalados.

Nueve días después, la amplitud de concesiones comenzaba a ser frenada; o se atendía aspectos no tenidos en cuenta. La carta real de 25 de mayo ${ }^{58}$, que ordenaba que los bienes comunales de las aljamas eran inalienables y quedaban a disposición de la corona, llegó muy tarde a Murcia y merced a un traslado. Lo que motivó la resolución concejil de recobrar lo ya vendido y hacerse cargo de lo que aún quedaba. Ya, anteriormente, el 22 de mayo, los regidores habían acordado que el procurador síndico comunicara a la aljama que las puertas del recinto no podian ser vendidas «porque son de la çibdad», y las destinaban a Santa Quiteria, casa de los carros del Corpus y casa del peso de la harina.

El 24 de julio, Pedro Saorín presentaba traslado de esta carta real, en que los Reyes manifestaban que estaban «ynformados que los judios para se yr venden las synagogas e osarios e exçesos e posesyones e casas e otras cosas comunes que tienen e son de la aljama», por lo que mandaban que nadie comprara tales bienes comunes y "Sy conpradas las tienen cobren el preçio que por ellas dieron so pena de las perder».

Los judíos, en su mayor parte, habían salido ya y como era conocido que sus convenios con los genoveses los habían hecho y hacían en Carpág. 51

58 SuÁREz Fernández, Documentos acerca de la expulsión de los judíos. Valladolid 1964 
tagena, el mismo día 24 de julio, tras ordenar que fuera pregonada la carta, el concejo designaba al regidor Lope Alonso de Lorca para que embargara cuantos bienes de esta naturaleza pudiera hallar y fuera a Cartagena para que le diera razón y cuenta de lo que habían vendido y obtenido por los osarios, sinagoga y cuantas cosas «comunes que tienen e son de la aljama», para que quedaran en depósito hasta que los Reyes decidieran lo que debía hacerse.

Y Alonso de Lorca, regidor y procurador síndico, nieto de converso, como mensajero del concejo marchó a Cartagena. De vuelta, el 4 de agosto, daba cuenta de su "enbaxada" y lo que había podido obtener de los bienes comunes de la judería. Informado que ciertos genoveses de Murcia se habían obligado por los judíos, convino con ellos que la cuestión fuera juzgada y sentenciada por el alcalde mayor. El cual, en su sentencia, condenó a los judíos y a los genoveses como sus fiadores al pago de 250.000 maravedíes; sentencia que Alonso de Lorca presentó al concejo, aparte de sus gastos por los diez días que estuvo en Cartagena para cumplir su misión, más los de la escritura ${ }^{59}$.

Las condiciones, en cierta forma positivas dictadas con anterioridad, a raíz de la orden de expulsión, comenzaron a mostrarse adversas al paso del tiempo y al tanto de cómo se habían traspasado las deudas y obligaciones, y el 10 de septiembre se detuvo el pago de las deudas dejadas por Ios judíos ${ }^{60}$, por entender y porque así se había denunciado, que eran producto de contratos usurarios. La que fue completada por otra de 30 de octubre ${ }^{61}$, dirigida a los mercaderes y genoveses de Burgos, Murcia, Cartagena y Toledo, ordenándoles la entrega de las cédulas de cambio que habían dejado los judíos por si habían incurrido en el delito de haber sacado oro, plata y otras cosas vedadas, por lo que merecerían perder sus bienes, aunque reconociéndoles que si eran legales, se les abonaría el 20 por 100 de su valor, toda vez que a nadie se le ocultaba el bajo

\footnotetext{
59 Regidor desde 22-XII-88 por renuncia de su padre Alonso de Lorca. Rehabilitado por los Reyes Católicos en 30-XII-91, ya que habia sido declarado inhábil por haber sido condenado por hereje su abuelo Alonso Lope de Lorca. La bula pontificia obtenida sería medio para lograr la carta real.

60 Detenciones en el pago, como la carta de espera por cuatro meses concedida a Iseo Fajardo y a su hijo Carlos de Guevara para pagar a Andrea de Mar una deuda traspasada por el judío Samuel Cohen al tiempo de salir del reino, entregada por fianza que otro genovés había dado. Molina Molina entiende que la sustitución de judios por genoveses fue beneficiosa por sus menores intereses, ya que se atuvieron a los legales y siempre con facilidades crediticias al concejo, compensadas con trato favorable en sus negocios (Molina MolinA, "Mercaderes genoveses en Murcia durante la época de los Reyes Católicos", M.M.M., n. ${ }^{\circ}$ II, pág. 282).

61 SUÁREZ, Documentos, pág. 228.
} 
precio que habían pagado por ellas. En noviembre, y atendiendo la solicitud de 11 mercaderes genoveses de Murcia, los Reyes ordenaban investigar los contratos que tenían de los judíos por si hubo logro o usura, y de no haberlo ordenaban su pago porque «ellos no avian cobrado las dichas debdas que los judios les avian traspasado en pago de debdas que les devian». Lo que tendría continuidad en los años siguientes.

Otra faz, otra imagen difícil de captar sería la personal de los judíos decididos a mantener su religión y, por ello, obligados a salir con los menguados bienes que pudieron llevar consigo, porque forzosamente hubieron de caer en manos de los genoveses, que no dejarían de aprovecharse de las oportunidades que se les ofrecía. Causa y motivo por las pesquisas que mandaron hacer los Reyes y considerable baja que posteriormente dictaron.

Porque hubieron de vender todo cuanto tenían. Por una pesquisa que mandó hacer el corregidor de Murcia sabemos que los judíos vendieron sus bestias a bajo precio a mercaderes genoveses y otros forasteros por medio de corredores colegiados, y por ello dispuso que cualquier vecino que tuviera necesidad de tales animales podría exigir su entrega en plazo de tres días, pagando tanto cuando hubiera abonado "el forastero" por ellas. En julio, Yanto Benzalay malvendía, al propio concejo por su derecho de laudemio, un obrador que tenía en la puerta de la judería. Y ésta pronto sería ocupada por los cristianos, ya que entonces el concejo autorizó mediante pregón la venta de hortalizas y toda clase de artículos en el interior del recinto ${ }^{62}$.

Difícil resulta cualquier intento de cifrar el número de los judíos murcianos que se embarcaron en Cartagena, aunque al aproximarnos al número de familias que en estos años se concentraban en la judería, cabe deducir que podrían ser en torno a las 700 personas. Poco más, porque no nos sirve conocer esos 16 barcos atestados de viajeros que, según Joseph Ha- Cohen, salieron de Cartagena el viernes 16 de abril —aunque el 16 de abril no era viernes y es fecha excesivamente próxima a 31 de marzo-, porque allí llegaron de otras procedencias, como los de La Mancha. Sólo el dato de que una de las carracas fue facilitada por el genovés Juan Antonio de Negro con ciertas dificultades, pues su propietario, su tío Juan Ambrosio, se negaba a cumplir el asiento concertado por estimar que el precio era bajo ${ }^{63}$.

62 En 10 de julio el concejo negaba a Rodrigo de Arróniz las obras que quería hacer en las casas "que conpro" en la judería, cerca deladarve, porque era perjuicio para la ciudad".

63 SuÁREZ, Documentos, 18-VI-92, págs. 434-435. 
Tampoco los que quedaron, pues forzosamente algunos hubieron de retrasar su salida por diversas incidencias; los datos de posibles conversiones faltan, fuera de Grimaldo y Peralta, de que ya hemos hecho mención.

En cuanto a los bienes comunales de la judería, pertenecientes a la Corona, sabemos que en agosto de 1492 Gonzalo Carranza pidió al concejo que rogaran a los Reyes le concedieran la sinagoga; los regidores eludieron hacerlo, si bien le ofrecieron escribir a Juan Cabrero, tiempo antes corregidor de Murcia y con amplia influencia cortesana. No la conseguiría. Este Gonzalo Carranza, judío converso casado con cristiana vieja según declaraba, pidió después, más codicia que por añoranza, al Consejo real que le dejaran y no impidieran vivir en las que habían sido sus casas en el barrio "que solía ser juderia», y por salvar suspicacias y prohibiciones alegaba que su conversión había sido tiempo antes de la expulsión. El Consejo real remitió la solicitud al corregidor para su resolución.

Los dos osarios, grande y pequeño, fueron concedidos el 20 de diciembre por mitad al monasterio de Santa Clara y al contino real Alonso Fajardo. Las puertas y la sinagoga, también bienes comunes, las donaron los Reyes a Alderete, quien hasta noviembre de 1495 no pudo resolver la cuestión en el concejo, que alegaba haber utilizado las puertas, tras su separación en las casas de los carros del Corpus y peso de la harina con anterioridad a la concesión real, así como la cal y ladrillos que allí obtuvieron ${ }^{64} \mathrm{y}$, por tanto, no se consideraban obligados a su devolución. Todo se resolvió amigablemente con la entrega de 2.000 maravedíes a su vecino y renuncia de éste a su propiedad.

64 Orden en 4-IX-92 a Alonso Sánchez para que derribara el portal de la judería, que está "cabo de su casa e ponga ante escrivano el ladrillo de la dicha puerta e lo tenga de manifiesto para las obras de la çibdad". 